\title{
Holocene fluvial landscape evolution driven by sea level and tectonic controls in the Gangkou River, Hengchun Peninsula
}

\author{
Jia-Hong Chen ${ }^{1}$, Shyh-Jeng Chyi ${ }^{1}$, Jiun-Yee Yen $^{2, *}$, Lih-Der Ho ${ }^{1}$, Christopher Lüthgens ${ }^{3}$, \\ Pei-Ling Wang ${ }^{4}$, Li-Hung Lin ${ }^{5}$, I-Chin Yen ${ }^{6}$, Chia-Hung Jen ${ }^{1}$, and Jyh-Jaan Steven Huang ${ }^{5,7}$ \\ ${ }^{1}$ Department of Geography, National Kaohsiung Normal University, Kaohsiung City, Taiwan \\ ${ }^{2}$ Department of Natural Resources and Environmental Studies, National Dong Hwa University, Hualien City, Taiwan \\ ${ }^{3}$ Institute of Applied Geology, University of Natural Resources and Life Sciences, BOKU, Vienna, Austria \\ ${ }^{4}$ Institute of Oceanography, National Taiwan University, Taipei City, Taiwan \\ ${ }^{5}$ Department of Geosciences, National Taiwan University, Taipei City, Taiwan \\ ${ }^{6}$ Institute of Applied Geology, National Central University, Taoyuan City, Taiwan \\ ${ }^{7}$ Institute of Geology, University of Innsbruck, Innsbruck, Austria
}

\section{Article history:}

Received 8 November 2020

Revised 11 March 2021

Accepted 8 April 2021

\section{Keywords:}

Fluvial landscape, Hengchun Peninsula, Underfit stream, Sea-level change, Gangkou River, River terrace, Holocene maximum flooding surface (HMFS), Lagoon

\section{Citation:}

Chen, J.-H., S.-J. Chyi, J.-Y. Yen, L.-D. Ho, C. Lüthgens, P.-L. Wang, L.-H. Lin, I.-C. Yen, C.-H. Jen, and J.-J. S. Huang, 2021: Holocene fluvial landscape evolution driven by sea level and tectonic controls in the Gangkou River, Hengchun Peninsula. Terr. Atmos. Ocean. Sci., 32, 339-360, doi: 10.3319/TAO.2021.04.08.01

\begin{abstract}
The fluvial landscape of the Hengchun Peninsula in southernmost Taiwan is generally characterized by a narrow river and a wide valley plain. Such underfit stream features are unusual in tectonically active areas such as Taiwan. In this research, we hypothesize that the relative sea level change since the end of the last glacial period might be the main factor driving the formation of this type of landscape on the relatively recently emerged Taiwan Island. The Gangkou River is among the largest and most pristine rivers on the Hengchun Peninsula, and well-preserved river terraces and bedrock exposures occur along the river and river mouth. Therefore, the Gangkou River was thoroughly surveyed to investigate the factors shaping the landscape and to determine the landscape evolutionary history. Our research indicates that the average uplift rate of the Gangkou River is $1.5-1.7 \mathrm{~mm} \mathrm{yr}^{-1}$. Because of the low uplift rate, the rising sea level after the last glaciation caused widespread aggradation in the Gangkou River. At approximately 8.0 - 7.7 ka, maximum flooding occurred, and the sea level subsequently remained stable, while the aggradation stopped after $7.1 \mathrm{ka}$. Incision followed, forming the high terraces, and starting in the Little Ice Age, repeated aggradation and incision occurred, forming the low terraces. These processes produced the current landscape of the Gangkou River. Overall, the uplift rates calculated from this research are relatively low in this tectonically active area.
\end{abstract}

\section{INTRODUCTION}

The Hengchun Peninsula (HP) is the southernmost tip of the island of Taiwan (Fig. 1a). The island is thought to have formed from the oblique collision between the Luzon arc and the Eurasian continent, which occurred in northern Taiwan and propagated southward (Suppe 1981, 1984; Huang et al. 1997). Therefore, the HP is regarded as the youngest of the Taiwan orogenic belt and emerged above sea level very recently (Chang et al.2003). This study focuses on the Gangkou River (catchment area: $102 \mathrm{~km}^{2}$ ), which

\footnotetext{
* Corresponding author

E-mail:jyyen@gms.ndhu.edu.tw
}

occupies the eastern part of the HP and flows mainly to the south before turning east into the Pacific Ocean (Fig. 1b). The main trunk of the Gangkou River is $35 \mathrm{~km}$ in length and has a meandering channel, and the mean gradient is approximately $1.2 \%$. The lower reach of the Gangkou River can be described as an underfit stream because it features a narrow riverbed flowing through a very wide river valley (Dury 1964). The width of the active river is often less than $10 \%$ of the river valley, which is composed of river terraces and the current riverbed (Fig. 2). This is in stark contrast to the rivers just slightly north of the peninsula.

Recently, a similar type of landscape has been reported 
on North Island of New Zealand (Ota et al. 1988, 1990; Berryman et al. 1992; Heap and Nichol 1997; Litchfield and Berryman 2005; Wilson et al. 2007a, b; Clement et al. 2010; Litchfield et al. 2010; Litchfield and Clark 2015), coastal lowlands in eastern Japan (Ishihara et al. 2012), California Channel Islands in the western US (Schumann et al. 2014, 2016), and the Lower Tagus Valley in central Portugal (Van der Schriek et al. 2007; Vis et al. 2008, 2010; Vis and Kasse 2009). Most studies have found that these areas have low uplift rates, and the rising sea level after the last ice age shifted the coastlines landward, slowing sediment transport and consequently causing burial of the river channels in the lower reaches. After the stabilization of the sea level in the midHolocene, slow and steady tectonic uplift caused the downcutting of the buried river channel and formed river terraces.

Most drainage basins on the HP feature a similar underfit stream landscape, especially in the eastern part of the peninsula. This feature is seldom discussed in the literature. Unlike the previously reported cases, rivers along the mountain front on the eastern side of the HP all flow eastward into the Pacific. The hilly landscape of the eastern HP drops to the Pacific Ocean immediately in front of the mountain front without a well-developed fluvial plain or delta (Fig. 2). In other words, there is no buffer zone between the mountains and the ocean. During recent millennia, the uplift rates of the HP have varied widely both in space and time. Chen and Liu (1993) and Lüthgens et al. (2018) show that the uplift rates of marine terraces on the eastern HP are $2.2-2.1$ and 0.9 - $1.4 \mathrm{~mm} \mathrm{yr}^{-1}$, respectively, while Chen and Liu (1993), Chen et al. (2005b), and Chen et al. (2014) concluded that the western part of the HP has uplift rates greater than $3 \mathrm{~mm}$ $\mathrm{yr}^{-1}$. Under these circumstances, it is most likely that the terraces developed in the Gangkou River were probably influenced by the relative sea level change directly without delay or interruption from any buffer zone in between. Therefore, the Gangkou River basin is an ideal place to study relative sea level change by synthesizing terrace landforms, terrace deposits and other sedimentary features nearby, such as the distribution of river terraces, relative heights of river terraces, and observations from terrace deposits and drill cores.

Our investigation showed that there are two flights of terraces along the Gangkou River: high river terraces and low river terraces (including fan terraces that developed at approximately the same time as the above two). The high river terraces are generally 10 or even 20 m higher than the current active riverbed, and the low river terraces are approximately $5 \mathrm{~m}$ above the current riverbed. The material underlying the current riverbed and comprising the high river terraces in the downstream and estuary areas is mainly thick very fine-grained mud. This is in stark contrast to the other low terraces in the river basin that are composed mostly of coarse sand and gravel, as are most of the river terraces in southern Taiwan (Hsieh and Chyi 2010; Kung and Chyi 2012; Hsieh et al. 2014). Because of the contrast in the composition of river terraces and because the landscape indicates a low uplift rate of the newly emerged section of the orogenic belt of Taiwan, this study aims to investigate the topographic and sedimentary features of the river terraces in the lower reach of the wide valley section of the Gangkou River (Fig. 2). Both field surveys and geological borehole drilling were performed to investigate how sea level change and tectonic uplift influence the burial of a river valley, the

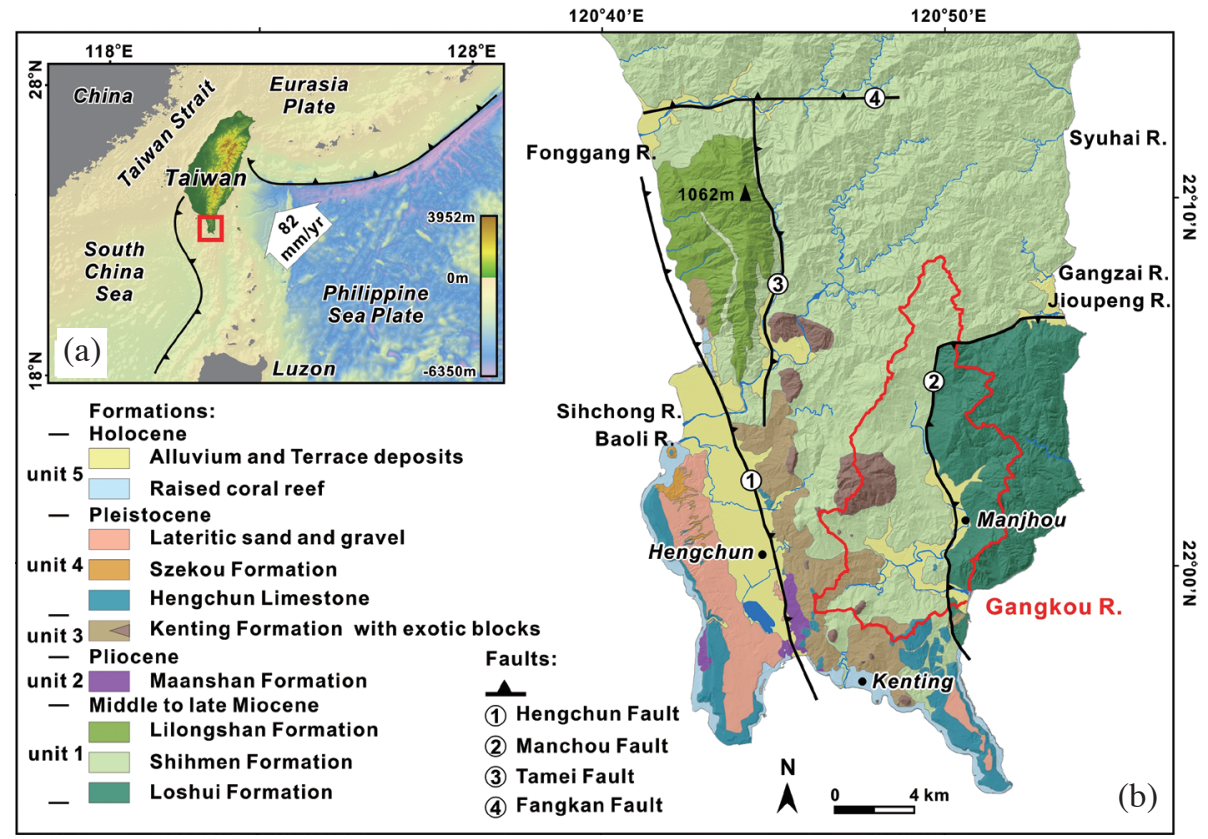

Fig. 1. The geographic locations and geological map of the Hengchun Peninsula (HP). (a) The Hengchun Peninsula marked by the red box. (b) Geological map of the Hengchun Peninsula modified from Chen et al. (2005b) and the extent of the Gangkou River basin marked by the red solid line. 


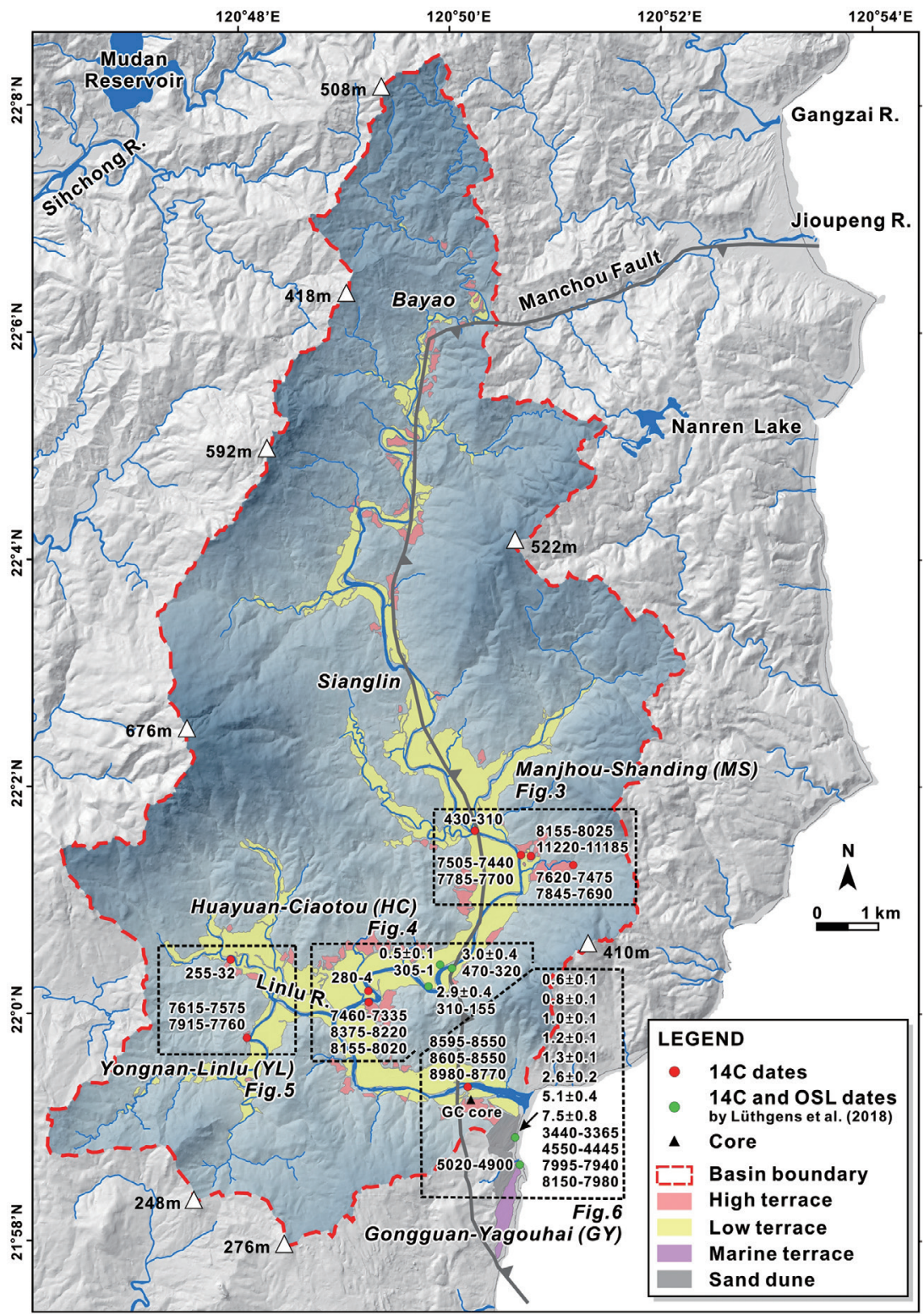

Fig. 2. The distribution of river terraces, marine terrace, sand dunes, and radiocarbon dates in the Gangkou River basin, and the base map is constructed from the 5-m digital terrain model (DTM) issued by the Ministry of the Interior. This study focuses on the geomorphic and sedimentary features between the middle reach and the lower reach. Therefore, we divide the field survey results into four areas that are discussed separately, including the Manjhou-Shanding (MS) area (Fig. 3), Huayuan-Ciaotou (HC) area (Fig. 4), Yongnan-Linlu (YL) area (Fig. 5), and GongguanYagouhai (GY) area (Fig. 6). 
processes of river terrace formation, and average uplift rates on a ten thousand-year time scale on the eastern HP. This is the first time the Holocene fluvial landscape within the hilly areas of the HP has been evaluated, and this work provides insight into the long-term landscape evolution of the region.

\section{STUDY AREA}

\subsection{Geological Features}

The Philippine Sea plate is moving at a rate of $82 \mathrm{~mm} \mathrm{yr}^{-1}$ relative to the Eurasian plate (Yu et al. 1997) and has formed the island of Taiwan through oblique arccontinent collision and the development of a fold and thrust belt. The low-relief HP represents the southernmost part of the emerged orogenic belt (Suppe 1984; Yu and Lu 1995; Byrne and Liu 2002) (Fig. 1a).

According to age and lithofacies, the HP has five major geological strata (Chen et al. 2005b; Chen 2016) (Fig. 1b). Four of the geological strata can be observed in the Gangkou River basin. The oldest units are middle to late Miocene turbidite sequences called the Loshui Formation and Shihmen Formation, which are made up of sandstone, interbed sandstone and shale, and pebble conglomerates (the pebble conglomerate is called the Shitzutou Conglomerate). The unit unconformably overlying these strata is an early Pleistocene olistostrome (sedimentary mélange) called the Kenting Formation, which is made up of a highly sheared mudstone matrix with exotic blocks. Stratigraphically upward are the early to late Pleistocene Hengchun Limestone and lateritic sand/gravel partially exposed on summits and hillslopes in the lower reach. The youngest unit in the area is composed of Holocene terrace deposits, modern alluvium, and the latest uplifted coral reef.

Faults in the HP are mostly reverse faults and dip eastward. The Hengchun Fault lies in the western part of the HP, where the uplift rates of the hanging wall and footwall are $4.0-5.6$ and $-0.1 \mathrm{~mm} \mathrm{yr}^{-1}$, respectively (Chen et al. 2014). The Manchou Fault is located in the eastern part of the HP, and the main trunk of the Gangkou River is mainly located along or on the side of the Manchou Fault (Figs. 1b and 2). Studies show that the Manchou Fault is less active than the Hengchun Fault, and the vertical and horizontal displacement rates on both sides are similar (Chen 1993; Chen et al. 2005a; Giletycz et al. 2015). However, repeated leveling surveys (2002 - 2013) by Lee et al. (2014) showed that the Gangkou River area changed from subsidence to uplift following the $2006 \mathrm{M}_{\mathrm{w}} 7$ Pingtung earthquake off the HP, and approximately $2 \mathrm{~km}$ west of the Gangkou River mouth, there seems to be a faint boundary separating the two uplift patterns.

\subsection{Geomorphologic Features}

The landscape of the Gangkou River can be described predominantly as a meandering underfit stream (Fig. 2). The river terraces and modern active riverbed form a very wide river valley within the hills of the HP. The section with a wide river valley accounts for approximately $74 \%$ of the total length of the Gangkou River. The section of the main trunk between Bayao and Sianglin is $11 \mathrm{~km}$ in length (31\% of the total main trunk length), the mean gradient is approximately $1 \%$, and the river valley is $300 \mathrm{~m}$ in width, almost the same as the amplitude of the river meanders. Unpaired terraces were formed by the meandering process. Additionally, the section between Sianglin and the river mouth is 15 $\mathrm{km}$ long (43\% of the main trunk), the mean gradient is approximately $0.4 \%$, and this section has the most prominent underfit stream landscape, with a river valley width between 500 and $1000 \mathrm{~m}$ and an active river width of less than $10 \%$ of the width of the river valley. Fluvial landscapes with similar proportions have also been documented in the lowlands of England and in Wisconsin in the U.S. (Dury 1965).

The hills of the eastern HP drop down to sea level very close to the river mouth of the Gangkou River. Because the tidal range here is approximately $1.9 \mathrm{~m}$ (Yang et al. 2012), the river mouth is a microtidal environment dominated by wave processes (Hayes 1975; Dalrymple et al. 1992). The river mouth is usually blocked by barriers, which typically produce a swath of relatively still water extending landward for several hundred meters to $1 \mathrm{~km}$. It is worth mentioning that Lüthgens et al. (2018) investigated the coastal landscape south of the Gangkou River mouth. They reported an $\sim 8 \mathrm{ka}$ estuarine muddy bed, showing that the river flowed $\sim 600 \mathrm{~m}$ south of its present position or, more likely, formed an estuary at least $700 \mathrm{~m}$ wide (including the present river mouth), apparently caused by the Holocene sea level rise. Above this $\sim 8 \mathrm{ka}$ mud lies a bed of gravelly beachrock $(\sim 4.5 \mathrm{ka})$ signifying the end of the marine transgression. Approximately $400 \mathrm{~m}$ to the south, shells on a marine terrace yield a ${ }^{14} \mathrm{C}$ date of $\sim 5.0 \mathrm{ka}$. The fact that this date is derived from an elevation $5 \mathrm{~m}$ higher than the $\sim 4.5 \mathrm{ka}$ beachrock reveals northward tectonic tilting. Moreover, by using optically stimulated luminescence (OSL) dating methods, Lüthgens et al. (2018) showed an episode of coastal and fluvial aggradation starting at approximately $2.5 \mathrm{ka}$, in conjunction with the building of the beach/sand dune on the $\sim 4.5 \mathrm{ka}$ beachrock and the genesis of low-level $(<5 \mathrm{~m}$ high) terraces along the river. Therefore, the lack of buffering landscape features, such as alluvial plains, alluvial fans, fluvial landforms, and river terraces, along the Gangkou River was likely directly influenced by changes in relative sea level. Thus, the Gangkou River basin could provide clues to the relative motion between this area and the nearby relative sea level.

\section{METHODS}

\subsection{Field Survey and Radiocarbon Dating}

Maps of 1:5000 in scale and aerial photos of the study 
area published by the Aerial Survey Office (COA) of Taiwan were used to map the distribution of river terraces and measured height difference between the river terraces and the active riverbeds if possible. We conducted fieldwork to survey most of the terraces and mapped them in the lab. During surveys, we measured height differences with a handheld laser ranger and observed the boundaries between the cover deposits and bedrock strath of the river terraces. Furthermore, we also observed the sedimentary features of the cover sediments (including grain size, color, sedimentary structure, and texture, etc.), and the sediments are assigned corresponding codes based on the classes of lithofacies recognized by Miall $(1978,1996)$. Coordinates of sample locations and drilling locations were recorded using a global navigation satellite system (GNSS) with a virtual base station-real time kinematic (VBS-RTK) to reduce the uncertainty of the measurement to near-centimeter scale. Datable samples collected from terraces were sent to Beta Analytic Inc. and NTUAMS ${ }^{14} \mathrm{C}$-Dating Lab for age dating. The measured age results from both labs were changed to report an uncertainty of $1 \sigma$ (Table 1$)$. The results were then calibrated by using CALIB 7.04 to correct the ages (Reimer et al. 2013). Several previously published radiocarbon ages from Lüthgens et al. (2018) were recalibrated with the mentioned method and used here.

\subsection{Core Analysis}

As the narrow valley in the lower reach of the Gangkou River could have formed during the last ice age, the rising sea level slowed the outflowing sediments and buried the incised river valley, forming a wide sediment-filled plain. To better understand the history and magnitude of the sea level rise since the end of the last glacial period, we drilled a borehole to a depth of $30 \mathrm{~m}$ on the high river terrace, and the borehole is $0.9 \mathrm{~km}$ away from the river mouth (see location in Fig. 2). The retrieved core was described and further analyzed by performing particle size analyses and X-ray fluorescence core scanning analysis (XRF-CS), thus allowing sedimentary facies interpretation. The age model of the core was further performed by radiocarbon dating with suitable materials from the core, following the calibration procedure in section 3.1.

Particle sizes were analyzed by using a Microtrac S3500 laser particle size analyzer at the Department of Geography, NKNU. Samples were taken at an interval of $10 \mathrm{~cm}$ from the drilled core. Samples were treated using 35\% hydrogen peroxide to reduce the organic matter and washed with pure water. XRF-CS analyses were performed by using an Itrax-XRF Core Scanner at the Department of Geosciences, NTU. The scans were made by using a molybdenum tube set at $30 \mathrm{kV}$ and $45 \mathrm{~mA}$ with an exposure time of 10 seconds at $2 \mathrm{~mm}$ resolution [machine and sample preparation details can be found in Croudace et al. (2006)]. The semiquantita- tive XRF-CS results are used to discriminate terrestrial- and marine-sourced sediments in the studied core.

Ca variations can be mainly attributed to marine biogenic carbonates produced during the invasion of sea water, while $\mathrm{Ti}, \mathrm{K}$, and $\mathrm{Fe}$ may relate to siliciclastic materials with terrestrial origins. As $\mathrm{Ti}$ is a rather conservative element, we choose the logarithmic $\mathrm{Ca} / \mathrm{Ti}$ ratio as an indicator to reveal the influence of marine components and to reduce the potential matrix issues of XRF-CS (Calvert and Pedersen 2007; Rothwell and Croudace 2015). In addition, the $S$ content of marine sediment is generally between $0.3-3.0 \%$, and the terrestrial sediment is less than $0.3 \%$ (Keith and Degen 1959; Ishihara et al. 2012). The S intensity of XRF-CS is also used to support the significance of marine components. In particular, the limestone strata exposed partly in the study area are likely to cause a higher ratio of $\mathrm{Ca} / \mathrm{Ti}$. Therefore, the intensity of other elements must be considered to determine the source of the sediment.

\section{RESULTS}

The river terraces of the Gangkou River can be separated into four groups according to their geographical areas (Fig. 2): the Manjhou-Shanding (MS) area (Fig. 3), Huayuan-Ciaotou (HC) area (Fig. 4), Yongnan-Linlu (YL) area (Fig. 5), and Gongguan-Yagouhai (GY) area (Fig. 6). The main sedimentary profile of each area is presented in Fig. 7. From our field investigations, we found that the sediment underlying the coastal sand dunes is a mud layer dated to $\sim 8$ $\mathrm{ka}$ (Lüthgens et al. 2018). The high river terrace on the right bank of the Gangkou River in the GY area was chosen for geological drilling. A 30-m core (GC core) was recovered from this area for the aforementioned analyses.

\subsection{Manjhou-Shanding (MS) Area}

In this area (Fig. 3a), the high river terrace and the active riverbed have a height difference of $20.8 \mathrm{~m}$ (Fig. 3b). The terraces are composed of sediments that are $18.5 \mathrm{~m}$ in thickness and are underlain by bedrock composed of late Miocene turbidites (interbedded sandstone and shale). The exposed sediments on the upper part are alluvial fan facies, mainly brownish-yellow massive mud with clast-supported pebble beds within the mud layers (Fig. 3c). Charcoal samples recovered from the middle section of the covered sediments from the main trunk were dated to $7785-7700$ cal. BP and 7505 - 7440 cal. BP (Fig. 7). The deposition rate was calculated to be $5.9 \mathrm{~mm} \mathrm{yr}^{-1}$, and, therefore, the end of deposition was estimated to have occurred at approximately $6.1 \mathrm{ka}$. Furthermore, the tributary exposures show that the fan deposits overlie low-energy light-gray massive mud at the bottom of the terrace, and two charcoals were dated to 11220 - $11185 \mathrm{cal}$. BP and 8155 - 8025 cal. BP (Figs. 3d and 7). The deposition rate was therefore 
Table 1. Radiocarbon dates in the Gangkou River basin.

\begin{tabular}{|c|c|c|c|c|c|c|c|c|}
\hline Site $^{A}$ & Lab No. ${ }^{\mathrm{C}}$ & Material $^{\mathrm{D}}$ & Measured age (BP) & $\delta^{13} \mathrm{C}(\%)$ & $\begin{array}{c}\text { Conventional age } \\
(\mathbf{B P})^{\mathrm{E}}\end{array}$ & $\begin{array}{c}\text { Calibrated age } \\
(\text { Cal BP })^{\mathrm{F}}\end{array}$ & Height $(\mathbf{m})^{\mathrm{G}}$ & a.s.l. (m) \\
\hline \multicolumn{9}{|c|}{ Manjhou-Shanding (MS) } \\
\hline $3 \mathrm{c}$ & B-398756 & charcoal & $6720 \pm 30$ & -12.9 & $6920 \pm 30$ & $7785-7700$ & 10.8 & 40.7 \\
\hline $3 \mathrm{c}$ & B-398099 & charcoal & $6390 \pm 30$ & -12.7 & $6590 \pm 30$ & $7505-7440$ & 12.4 & 42.3 \\
\hline $3 \mathrm{~d}$ & B-386261 & charcoal & $9520 \pm 30$ & -10.4 & $9760 \pm 30$ & $11220-11185$ & 6.9 & 36.8 \\
\hline $3 \mathrm{~d}$ & B-379186 & charcoal & $7050 \pm 30$ & -11.8 & $7270 \pm 30$ & $8155-8025$ & 8.3 & 38.2 \\
\hline $3 \mathrm{e}$ & N-6400-1 & charcoal & $6687 \pm 92$ & - & - & $7620-7475$ & 1.3 & 68.2 \\
\hline $3 \mathrm{e}$ & N-6401-1 & wood & $6949 \pm 76$ & - & - & $7845-7690$ & 0.8 & 66.1 \\
\hline $3 \mathrm{f}$ & B-377599 & wood & $320 \pm 30$ & -25.6 & $310 \pm 30$ & $430-310$ & 1.9 & 37.5 \\
\hline \multicolumn{9}{|c|}{ Huayuan-Ciaotou (HC) } \\
\hline $4 \mathrm{~b}$ & B-419124 & charcoal & $7020 \pm 30$ & -10.4 & $7260 \pm 30$ & $8155-8020$ & 1.2 & 11.7 \\
\hline $4 \mathrm{~b}$ & B-408138 & charcoal & $7270 \pm 30$ & -11.7 & $7490 \pm 30$ & $8375-8220$ & 4 & 14.5 \\
\hline $4 b$ & B-419123 & charcoal & $6270 \pm 30$ & -10.8 & $6500 \pm 30$ & $7460-7335$ & 11.6 & 22.1 \\
\hline $4 a^{B}$ & B-379183 & charcoal & $240 \pm 30$ & -24.6 & $350 \pm 30$ & $470-320$ & 1.9 & 22.1 \\
\hline $4 a^{B}$ & B-379184 & charcoal & $310 \pm 30$ & -28.5 & $250 \pm 30$ & $310-155$ & 3.9 & 21.8 \\
\hline $4 a^{B}$ & B-379185 & charcoal & $250 \pm 30$ & -26.5 & $230 \pm 30$ & $305-1$ & 2.8 & 22.9 \\
\hline $4 \mathrm{c}$ & B-408135 & charcoal & $150 \pm 30$ & -24.6 & $160 \pm 30$ & $280-4$ & 2.3 & 16 \\
\hline \multicolumn{9}{|c|}{ Yongnan-Linlu $(Y L)$} \\
\hline $5 b$ & B-412463 & charcoal & - & - & $6980 \pm 30$ & $7915-7760$ & 9.2 & 29.1 \\
\hline $5 b$ & B-412462 & charcoal & $6530 \pm 30$ & -12.3 & $6740 \pm 30$ & $7615-7575$ & 9.4 & 29.3 \\
\hline $5 \mathrm{a}$ & B-412460 & charcoal & $120 \pm 30$ & -26.3 & $100 \pm 30$ & $255-32$ & 1.3 & 33.9 \\
\hline \multicolumn{9}{|c|}{ Gongguan-Yagouhai $(G Y)$} \\
\hline $6 b$ & B-384624 & wood & $7810 \pm 30$ & -26.5 & $7790 \pm 30$ & $8595-8550$ & 0 & 1 \\
\hline $6 \mathrm{~b}$ & B-384625 & wood & $7850 \pm 30$ & -27.2 & $7810 \pm 30$ & $8605-8550$ & 0 & 1 \\
\hline $6 c$ & B-386259 & wood & $8000 \pm 40$ & -26.8 & $7970 \pm 40$ & $8980-8770$ & -1.9 & -0.9 \\
\hline $6 d^{\mathrm{B}}$ & B-408139 & shell & $4290 \pm 30$ & 1.9 & $4730 \pm 30$ & $5020-4900$ & 8.2 & 8.2 \\
\hline $6 \mathrm{e}^{\mathrm{B}}$ & B-393640 & plant remains & $7020 \pm 30$ & -12.4 & $7230 \pm 30$ & $8150-7980$ & 2.1 & 2.1 \\
\hline $6 \mathrm{e}^{\mathrm{B}}$ & B-408130 & plant remains & $7220 \pm 30$ & -30.1 & $7140 \pm 30$ & $7995-7940$ & 3.2 & 3.2 \\
\hline $6 \mathrm{e}^{\mathrm{B}}$ & B-408131 & shell & $3950 \pm 30$ & 0.8 & $4370 \pm 30$ & $4550-4445$ & 3.3 & 3.3 \\
\hline $7^{\mathrm{B}}$ & B-408132 & shell & $3090 \pm 30$ & 1.2 & $3520 \pm 30$ & $3440-3365$ & 6.3 & 6.3 \\
\hline \multicolumn{9}{|c|}{ GC core } \\
\hline 8 & B-550648 & charcoal & $13510 \pm 40$ & -14 & $13690 \pm 40$ & $16615-16385$ & -17.1 & -16.1 \\
\hline 8 & B-436387 & wood & $7780 \pm 30$ & -26.6 & $7750 \pm 30$ & $8585-8480$ & 0.3 & 1.3 \\
\hline 8 & B-436386 & wood & $7530 \pm 30$ & -26.8 & $7500 \pm 30$ & $8380-8315$ & 3.3 & 4.3 \\
\hline 8 & B-436385 & wood & $7190 \pm 30$ & -27.1 & $7160 \pm 30$ & $8000-7960$ & 5.5 & 6.5 \\
\hline 8 & B-436384 & wood & $6750 \pm 30$ & -27.9 & $6700 \pm 30$ & $7590-7520$ & 8.6 & 9.6 \\
\hline
\end{tabular}

Note: A: For sample sites, refer to Figs. 2, 3, 4, 5, 6, 7, and 8. B: Dates cited from Lüthgens et al. (2018). C: B is Beta Analytic Inc., and N is NTUAMS ${ }^{14} C$-Dating Lab. D: Assuming $\Delta R=0$ for calcium carbonate and shell samples. E: Conventional radiocarbon age corrected for isotopic fractionation, calculated using $\delta^{13} C$ values. F: Calibrated (10 range) using the program CALIB 7.04 (Reimer et al. 2013). G: The sample heights were relative to the modern riverbed, and the samples from the coastal area correspond to local mean sea level. 

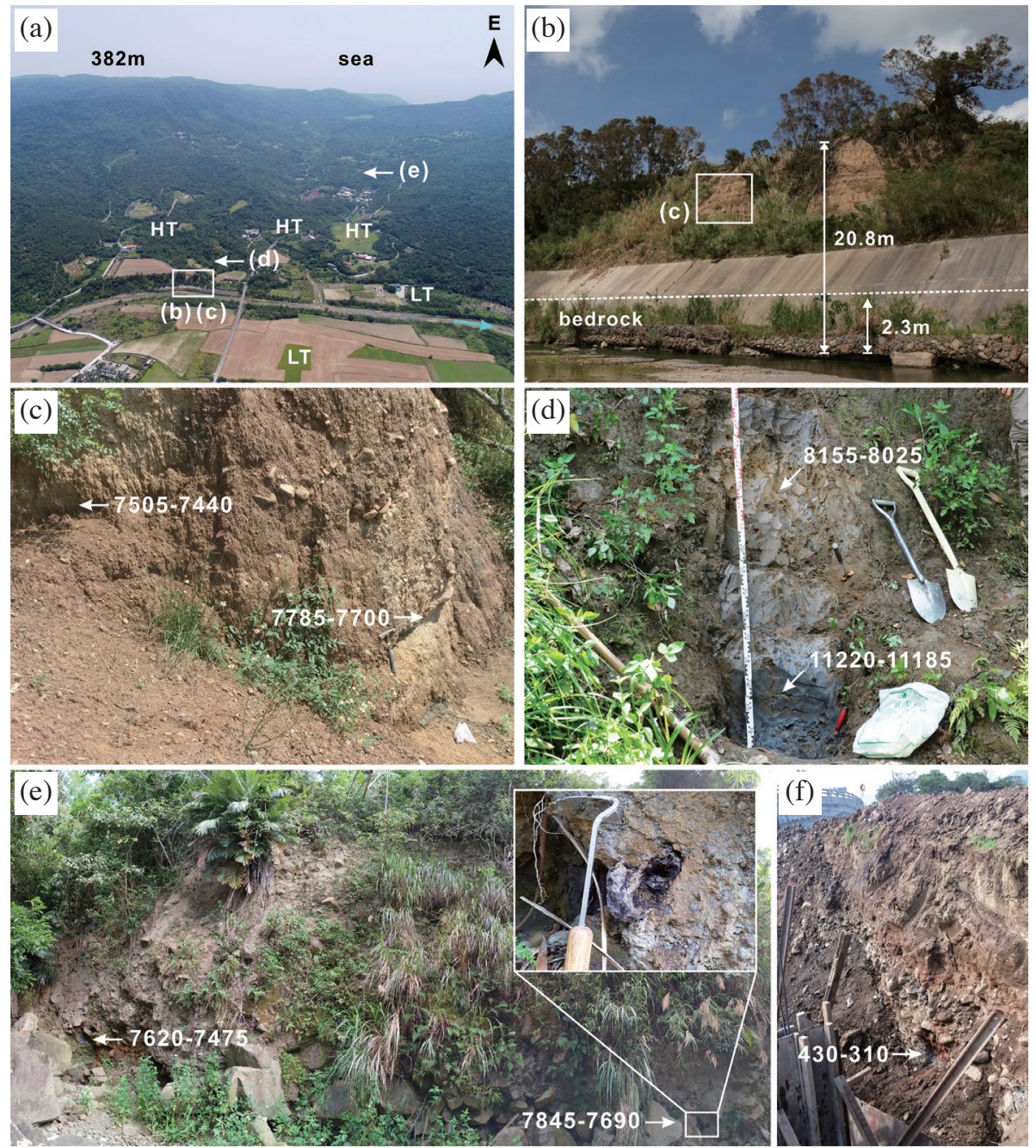

Fig. 3. Schematic diagram of river terraces, sedimentary profiles and chronology in the Manjhou-Shanding (MS) area. (a) Aerial view of the general landscape of the MS area. This photograph was taken from Manjhou facing east. This area is close to the upper limit of the underfit stream landscape. Tributaries with short flow paths and low discharge have developed wide high terraces (HT) on the left of the mainstream. (b) High terrace with a height of $20.8 \mathrm{~m}$ are distributed on the left bank. The terrace scarp can be observed at the bedrock surface of $2.3 \mathrm{~m}$ in height under the scoured levee, and an $11.8 \mathrm{~m}$ thick deposit was exposed. (c) In the upper part of the high terrace scarp, alluvial fan deposits crop out, and two samples of radiocarbon dating were obtained. (d) Sedimentary profile of the bottom of the high terrace approximately $2.5 \mathrm{~m}$ high on the left bank of the tributary. The main sedimentary feature is massive mud, which is similar to deposits on a floodplain or in low-energy environments. Because this terrace has the same terrace surface as the aforementioned terrace, the two profiles should be related to the upper and lower sequences. (e) This high terrace could extend at least $900 \mathrm{~m}$ upstream and is composed of exposed debris flow deposits with extremely poor roundness and some boulders larger than $1 \mathrm{~m}$ on the fanhead. Two samples were collected here: charcoal in the mud lens and a buried tree trunk. (f) Low terraces (LT) composed of river channel deposits. Above the bedrock surface, there are massive sand and gravel layers with imbricate structure and thin discontinuous mud layers. 

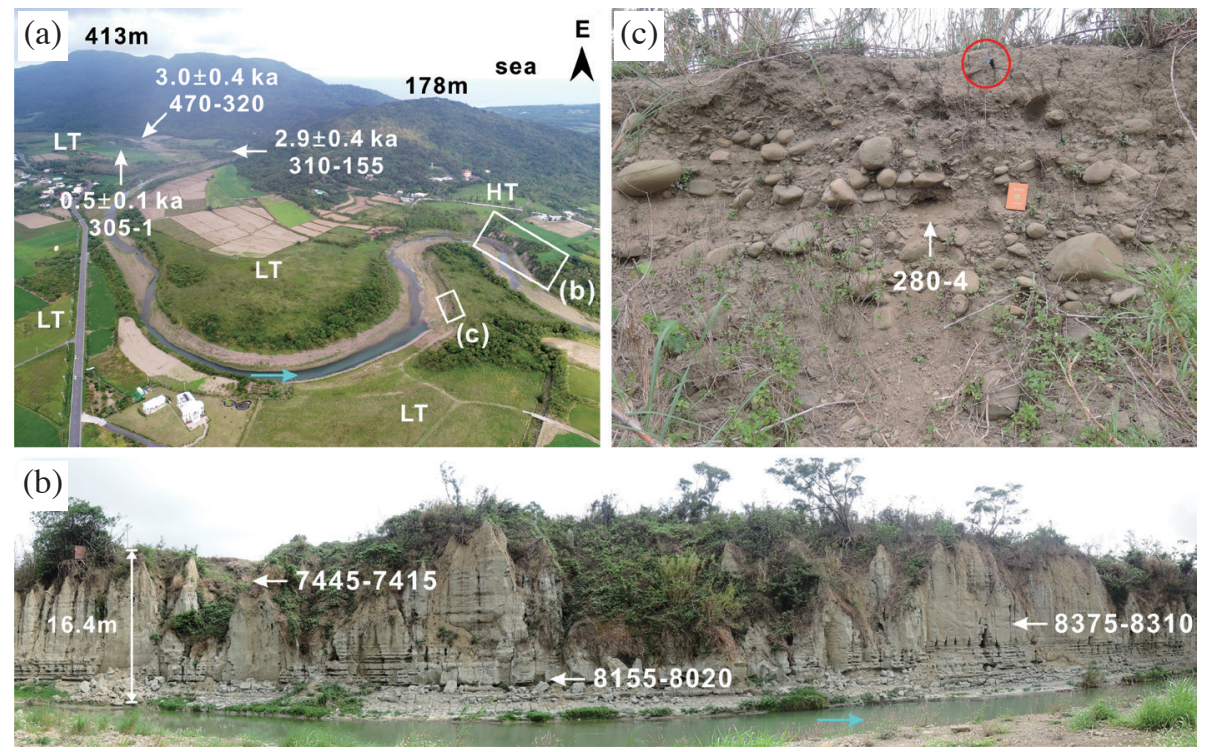

Fig. 4. Schematic diagram of river terraces, sedimentary profiles and chronology in the Huayuan-Ciaotou (HC) area. (a) Aerial view of the general landscape of the $\mathrm{HC}$ area. This photograph was taken from Ciaotou facing east. This is the most prominent underfit stream section. (b) High terrace (HT) with heights of approximately $16-18 \mathrm{~m}$ are located on the left bank, and the sedimentary profile extends approximately $180 \mathrm{~m}$ from east to west. The terrace scarp is mainly composed of massive mud of floodplain deposits. (c) The low terraces (LT) are composed of sand and gravel with an imbricate structure, and the massive sand at the top sometimes contains modern plastic waste (marked by a red circle). The sedimentary facies of these sites are all categorized as fluvial deposits. Furthermore, Lüthgens et al. (2018) also presented three ages based on radiocarbon dating and three ages based on OSL dating in the nearby low terraces.
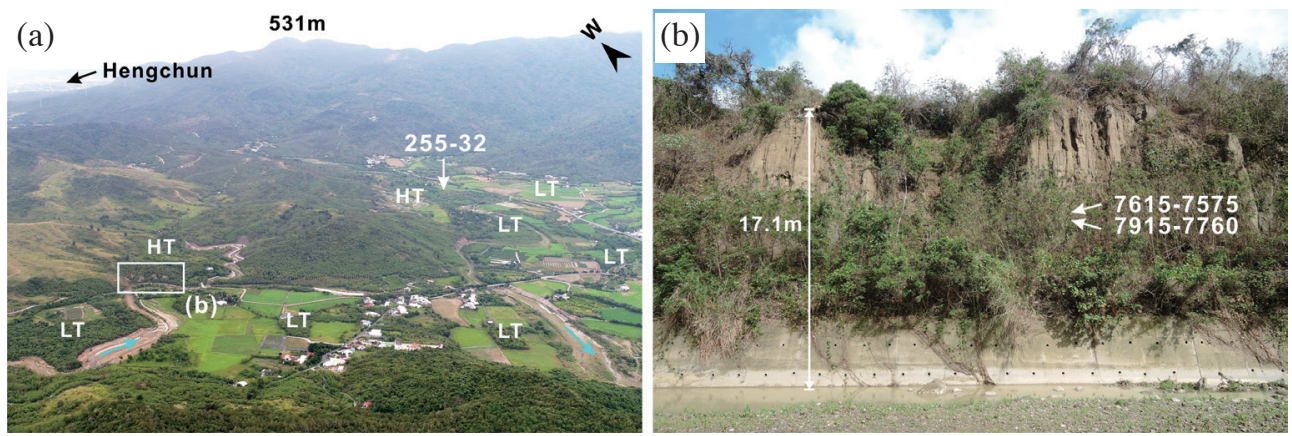

Fig. 5. Schematic diagram of river terraces, sedimentary profiles and chronology in the Yongnan-Linlu (YL) area. (a) Aerial view of the general landscape of the YL area. This photograph was taken from Ciaotou facing northwest. The low terraces (LT) widely distributed in this area are composed of sand and gravel deposits with imbricate structure. (b) There are few high terraces in this area. One high terrace (HT) is on the left bank of the tributary, and the sedimentary profile extends from northeast to southwest by approximately $60 \mathrm{~m}$. The upper part of the profile showed sediment approximately $14 \mathrm{~m}$ thick and was composed of massive mud similar to floodplain deposits. The lower part is blocked by levees, and it is uncertain whether the bedrock crops out. 

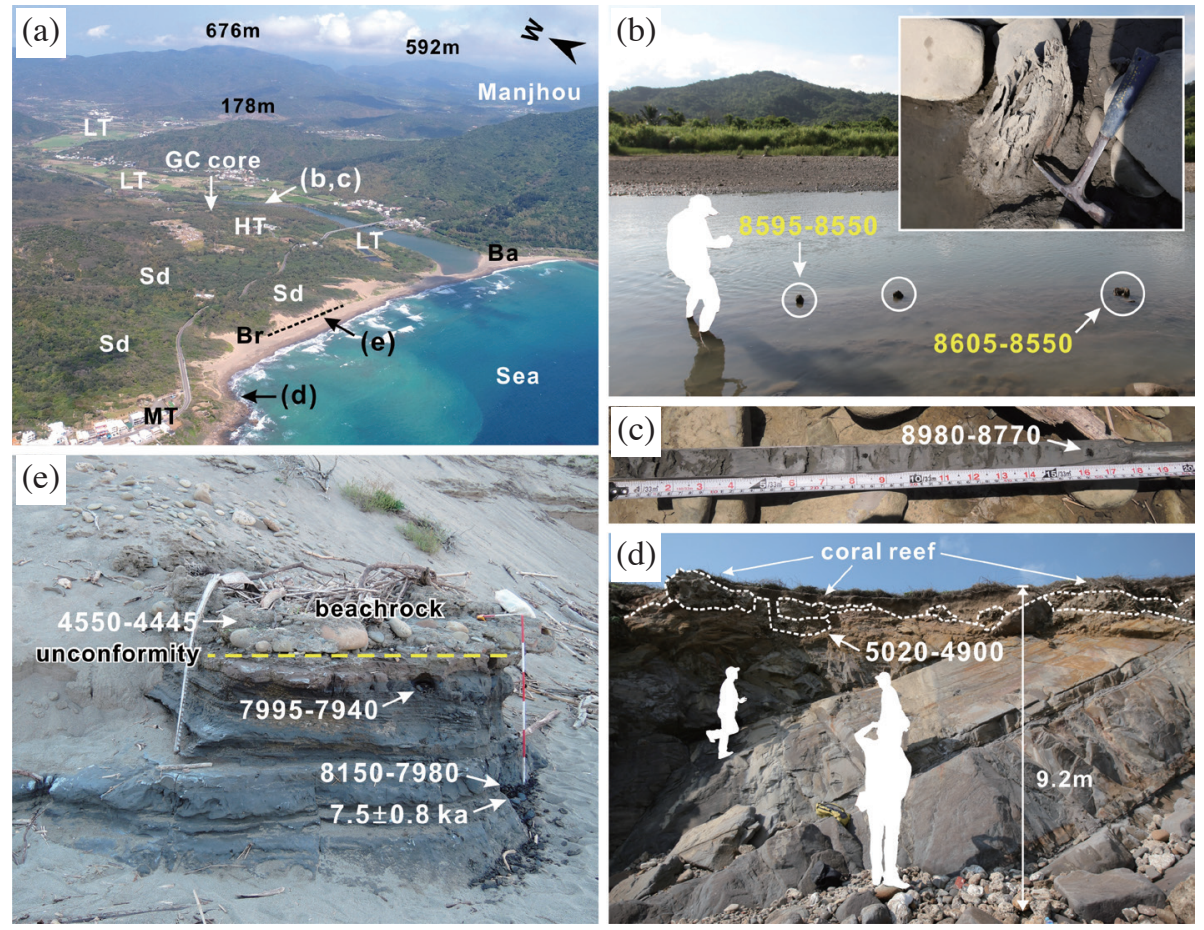

Fig. 6. Schematic diagram of river terraces, sedimentary profiles and chronology in the Gongguan-Yagouhai (GY) area. (a) Aerial view of the general landscape of the GY area. Most of the time except during the typhoon season, the river mouth is closed by the barrier (Ba), forming an estuarine environment, and the sand dune (Sd), beachrock (Br), and marine terrace (MT) are distributed on the southern bank. (b) Several buried tree trunks can be observed on the muddy riverbed approximately $1 \mathrm{~km}$ away from the current river mouth, and they have similar radiocarbon dates. (c) The mud layer is at least $2 \mathrm{~m}$ thick under the riverbed, based on hand auger observations, and a charcoal sample was found at a depth of $1.9 \mathrm{~m}$. (d) The marine terrace $9.2 \mathrm{~m}$ high is composed of $7.6 \mathrm{~m}$ high sandstone bedrock and $1.6 \mathrm{~m}$ thick coral reef and deposits, and a shell sample was collected between the crevices of the coral reef. (e) A residual mud $1.4 \mathrm{~m}$ thick is exposed under the sand dune, and the beachrock unconformably covers it. Then, the beachrock was covered by sand dunes. The dates of (d) and (e) both refer to Lüthgens et al. (2018), and all dates are marked in the stratigraphic column in Fig. 7. 

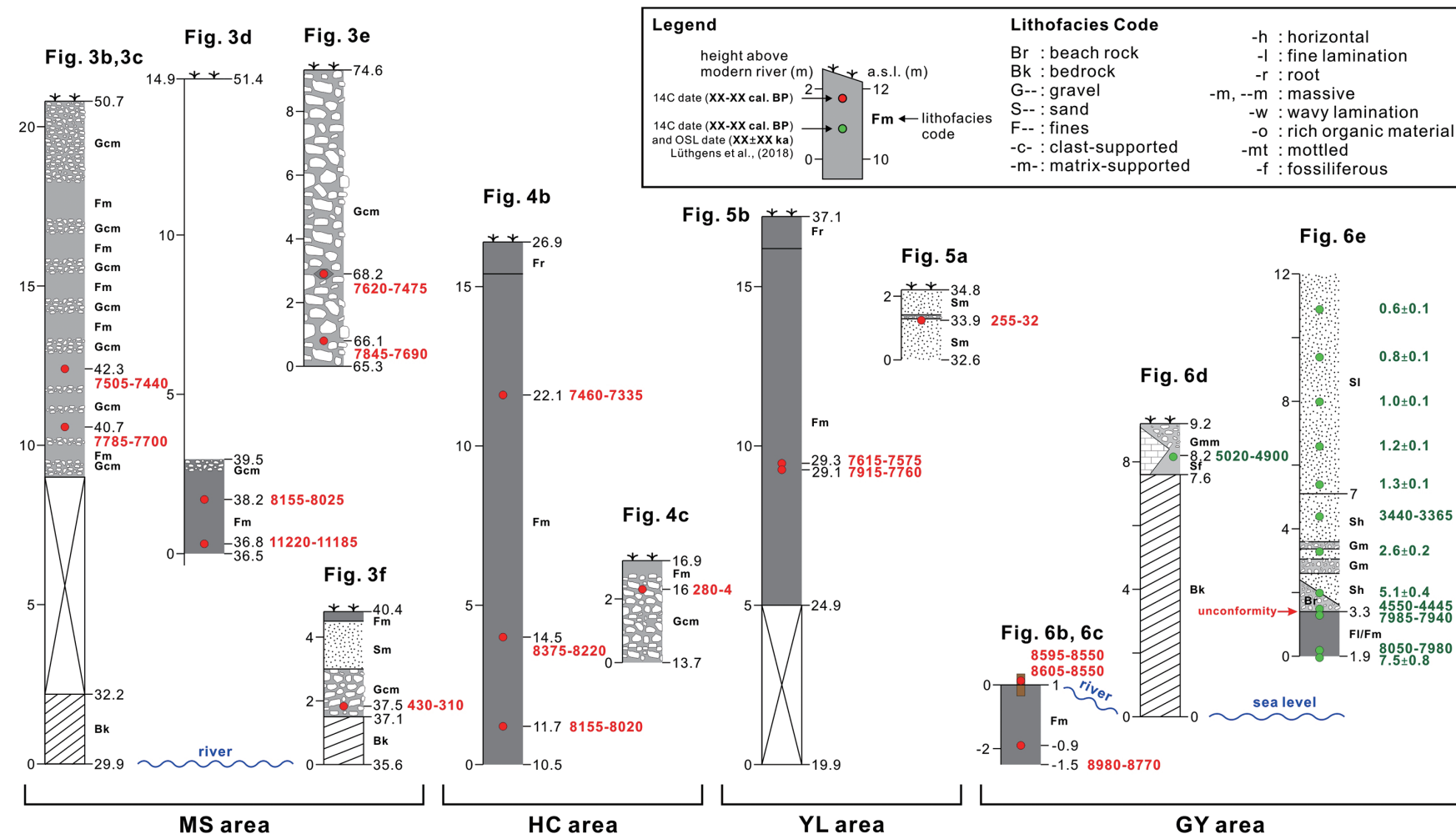

Fig. 5b $+* x 37.1$

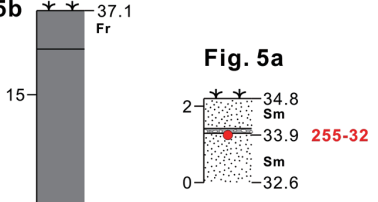

Fig. $6 e$
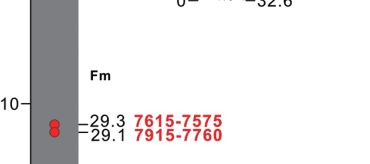

Fig. 6d

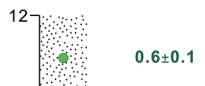

$\sqrt{3} \quad 0.6 \pm 0.1$

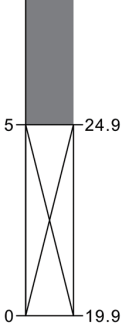

$\mathrm{HC}$ area

YL area

GY area

Fig. 7. Stratigraphic columns of river terraces, marine terrace and sand dune investigated in the study area. See Figs. 2 to 6 for location and photos. The red and green dots with numbers indicate the sites of radiocarbon and OSL dates, and lithofacies codes are used to indicate the sedimentary characteristics.

approximately $0.5 \mathrm{~mm} \mathrm{yr}^{-1}$ according to the height and age of the charcoal samples in the terrace deposits. Furthermore, this high terrace could extend at least $900 \mathrm{~m}$ upstream of the tributary, and we also observed that the top of the terrace is covered by coarse-grained debris flow deposits (Fig. 3e). The ages of the debris flow are $7620-7475$ cal. BP and 7845 - 7690 cal. BP (Fig. 7), which coincide with the ages of the terrace scarp on the side of the main trunk. Judging from the pattern of the contours, the above three positions should be the same terrace surface, and the grain size gradually decreases downstream.

Several terrace flights were found in the low terraces in this section, and their height differences with the active riverbed are approximately $2-5 \mathrm{~m}$. These terraces are composed of alluvial sand/mud and clast-supported gravel with imbricate structures. Among these low terraces, one wood sample was recovered from a terrace deposit with a surface height of $4.8 \mathrm{~m}$ above the active riverbed and a thickness of $3.3 \mathrm{~m}$ (Fig. 3f). The age was dated to $430-310 \mathrm{cal}$. BP (Fig. 7). Modern plastic wastes can be seen within the lowest flight of the terraces ( $2 \mathrm{~m}$ above the current riverbed).

Based on field investigations and laboratory data, a preliminary interpretation of the history of this area was developed. We consider that the MS area began to experience widespread aggradation by at least $11.2 \mathrm{ka}$ and that differ- ent sedimentary facies were deposited in different periods. According to our calculation, the deposition rates were low during this stage and increased in the later stage. The aggradation lasted to approximately $6.1 \mathrm{ka}$. Following the incision stage, meandering of the river swept over the valley bottom and formed a wide river valley. Most of the wide valley is composed of a bedrock strath with a very thin sedimentary cover. The incision stage ended at approximately 430 - 310 yr BP, while small-scale, intermittent deposition, incision, and lateral erosion along the main trunk remain active in the present and have contributed to the formation of a wide river valley.

\subsection{Huayuan-Ciaotou (HC) Area}

The HC area is the most prominent area of the underfit stream, and the width of the active river is less than $5 \%$ of the width of the river valley (Fig. 4a). The high terrace in the $\mathrm{HC}$ area is approximately $16-18 \mathrm{~m}$ above the current riverbed (Fig. 4b). The outcrop observed in the cliff of the terrace is composed of a low-energy brownish-yellow massive muddy deposit. Near the base of this mud deposit, charcoal samples were recovered and dated to 8155 - 8020 cal. BP, 8375 - $8220 \mathrm{cal}$. BP, and 7460 - $7335 \mathrm{cal}$. BP in the top section (Fig. 7). Because we cannot determine whether 
the bottom two samples are contaminated or reworked, we calculated average deposition rates of approximately 15.1 or $8.4 \mathrm{~mm} \mathrm{yr}^{-1}$. The wide plain of the river valley is composed of flights of low terraces with minor height differences. The terraces are less than $5 \mathrm{~m}$ above the active riverbeds, and some of the lowest flights (less than $2 \mathrm{~m}$ above the active riverbed) also contain modern plastic wastes (Fig. 4c). Outcrops in the cliff faces are composed mostly of alluvial sand/mud and clast-supported gravels with imbricate structure, and one charcoal sample also recovered with an age of 280 - 4 cal. BP (Fig. 7). Lüthgens et al. (2018) also proposed OSL and ${ }^{14} \mathrm{C}$ dates for three outcrops of low terraces, including $3.0 \pm 0.4 \mathrm{ka} / 470$ - $320 \mathrm{cal}$. BP, $2.9 \pm 0.4 \mathrm{ka} / 310$ - $155 \mathrm{cal}$. $\mathrm{BP}$, and $0.5 \pm 0.1 \mathrm{ka} / 305$ - 1 cal. BP. However, as Lüthgens et al. (2018) point out, the OSL samples showed signs of incomplete bleaching prior to deposition, and because of that they may have to be interpreted as maximum ages.

Judging from the features of the terraces and their deposition rates, the $\mathrm{HC}$ area started to experience large-scale aggradation before approximately $8 \mathrm{ka}$, and it lasted until approximately $7.1-6.8 \mathrm{ka}$. Then, the river started incising, lateral erosion occurred, and a flood plain formed. A bedrock strath is not seen at the base of the terraces in this area, so the incision was limited to the materials deposited between 7 and $8 \mathrm{ka}$ and did not cut into the bedrock in this region. Repeated aggradation and incision may have started again at approximately $2.5 \mathrm{ka}$ due to changes in the sedimentary environment (Lüthgens et al. 2018). The incision stopped at approximately $0.4 \mathrm{ka}$, followed by intermittent and small-scale aggradation, lateral erosion, and incision in the main trunk to form the current landscape.

\subsection{Yongnan-Linlu (YL) Area}

The YL area is located along the southwestern tributary of the main Gangkou River, which is the main landscape with low terraces (Fig. 5a). The flat surface of the original high terrace has been eroded, with only a few remnants of terrace deposits remaining. The height difference between the highest terrace remnant of this flight and the active riverbed is approximately $17.2 \mathrm{~m}$ (Fig. 5b), which could be the minimum height difference of the original terrace. Currently, brownish-yellow massive muddy sediments crop out on the scarp of the terraces. Two charcoal samples from the mid-section cliff were dated to 7915 - $7760 \mathrm{cal}$. BP and 7615 - 7575 cal. BP (Fig. 7). The lower flights, where one charcoal sample was recovered and dated to 255 - 32 cal. BP, have a height difference of mostly less than a $5 \mathrm{~m}$ with the active riverbed (Fig. 7).

Because the locations of the two dating samples were too close, with a height difference that was too small to calculate a meaningful average deposition rate, we estimated the rate of $10 \mathrm{~mm} \mathrm{yr}^{-1}$ based on the information from nearby sections of the Gangkou River for the general history in this area. The YL area started to experience large-scale aggradation possibly before $8.8 \mathrm{ka}$, and it lasted until approximately $6.8 \mathrm{ka}$. The river incised after this period and developed a wide river flood plain. A bedrock strath was not observed at the base of the terrace deposit, which implies that only mild incision occurred during the incision period and that most of the landscape formed through intense lateral erosion and meandering. At the end of this mild incision period, the main trunk began to experience another small episode of aggradation, lateral migration, and incision, finally forming the current landscape.

\subsection{Gongguan-Yagouhai (GY) Area}

The GY area is located in the estuary region, and the landscape consists of river terraces, a marine terrace, coastal sand dunes and a wave-dominated bar-built estuary (Fig. 6a). The height difference between the high terrace surface and active riverbed is at least $13.8 \mathrm{~m}$ in the GY area, and no terrace deposit outcrop was found. The low terraces have the height difference of $5 \mathrm{~m}$ with the active river. The terraces flight incrementally steps down from 5 to $2 \mathrm{~m}$ toward the active riverbed, with each surface slightly tilted toward the river. The terrace deposits are also mostly alluvial sand/mud and imbricated clast-supported gravel, with some modern waste observed on the scarp of the lowest flight. Large tree trunks $15-20 \mathrm{~cm}$ in diameter were found standing in the riverbed in this GY area (Fig. 6b). Using a hand auger on the exposed tree trunks, we found that the discovered tree trunks were at least $2 \mathrm{~m}$ in height and in their original standing position. The bark near the surface of muddy deposits was dated to 8595 - 8550 cal. BP and 8605 - 8550 cal. BP. Charcoal recovered $1.9 \mathrm{~m}$ below the muddy riverbed was dated to 8980 - $8770 \mathrm{cal}$. BP (Figs. 6c and 7).

To the south of the Gangkou River mouth, the marine terrace is $9.2 \mathrm{~m}$ above sea level (Fig. 6d). Previous research (Lüthgens et al. 2018) dated fossil shells recovered from this marine terrace to 5020 - 4900 cal. BP (Fig. 7). Sand dunes have developed between the previously mentioned marine terrace and the river mouth of the Gangkou River (Fig. 2), and beneath the sand dunes, there is a laminated mud layer that is at least $1.4 \mathrm{~m}$ thick (Fig. 6e). Lying unconformably on top of the partially eroded mud layer, there is a layer of beachrock approximately $3.3-3.5 \mathrm{~m}$ above sea level. On top of the beachrock, there are the beach sand and aeolian sand deposits (Fig. 7). Lüthgens et al. (2018) also documented two pieces of fossil seagrass recovered from the exposed mud layer. These samples were dated to 8150 $7980 \mathrm{cal}$. BP and 7995 - $7940 \mathrm{cal}$. BP, and a corresponding OSL age of $7.5 \pm 0.8 \mathrm{ka}$ was also obtained. The beachrock yielded an age for a shell fossil of 4550 - 4445 cal. BP, and a similar OSL age of $5.1 \pm 0.4 \mathrm{ka}$. The sand dunes covering the beachrock also have shell fossil age of 3440 - 3365 cal. $\mathrm{BP}$, and six OSL dates between $2.6 \pm 0.2 \mathrm{ka}$ and $0.6 \pm 0.1 \mathrm{ka}$ 
(Fig. 7). Therefore, the sand dunes developed later than $3 \mathrm{ka}$ (Lüthgens et al. 2018).

From the features observed in the river terraces, marine terrace, and sand dunes, the GY area started to experience large-scale aggradation before $8.0 \mathrm{ka}$. The aggradation ended sometime thereafter, and by approximately $4.5 \mathrm{ka}$, the river had already incised to approximately $3.3-3.5 \mathrm{~m}$ above current sea level. This is the height of the boundary between the beachrock and the underlying remnant mud layer. The remaining mud discovered in the current river mouth indicated that at the maximum aggradation time, the location of the ancient river mouth was farther seawards and started to move landward to the current position at approximately $4.5 \mathrm{ka}$. This position was later covered by beachrock, beach sand, and sand dunes. Lüthgens et al. (2018) proposed that a beach developed at approximately $4.5 \mathrm{ka}$. During the incision period, the meanders started to incise the sediments deposited earlier and later formed a wide river valley. Intermittent aggradation occurred in the most recent period and formed the low terraces in this area. The lowest flight of these later terraces contains modern waste.

\subsection{GC Core Analysis}

The GC core can be categorized into five sections from bottom to top according to the features of the core (Fig. 8). They are described below:

Unit I is the bottommost unit of the core between - 30.0 and $-26.4 \mathrm{~m}$ from the surface of the terrace, corresponding to -16.2 to $-12.6 \mathrm{~m}$ relative to the current sea level. This layer features greenish-gray colored mud with nonprominent laminae. The matrix mud contains limestone and sandstone breccia and debris with brownish-yellow mottling. In the bottom part of the core, the partial laminae are slightly deformed, and a shear structure of approximately 50 degrees at a depth of $-28.5 \mathrm{~m}$ was observed. Charcoal recovered from $-29.9 \mathrm{~m}$ of the core was dated to $16615-16385 \mathrm{cal}$. BP. Unit II is a limestone boulder between -26.4 and $-22.9 \mathrm{~m}$ in the core and between -12.6 and $-9.1 \mathrm{~m}$ relative to the current sea level. This unit represents a cored carbonate boulder with cavities filled by greenish-gray mud with brownish-yellow mottling. It is worth noting that carbonate boulders of similar size have also been observed in the nearby riverbed, and a large amount of carbonate breccia and boulders can also be seen in the riverbed and on the high terrace surfaces in the $\mathrm{HC}$ area, which is approximately $6-7 \mathrm{~km}$ away upstream from the river mouth.

From XRF-CS analyses, Unit I has relatively low S contents and relatively high $\mathrm{K}$ and $\mathrm{Fe}$ contents, indicating a terrestrial environment, and the relatively high $\log (\mathrm{Ca} / \mathrm{Ti})$ ratio may be affected by carbonate breccia and debris. In addition, although Unit II is affected by a carbonate boulder and has extremely high $\log (\mathrm{Ca} / \mathrm{Ti})$ values, the mud filling the cavities has obvious fluctuations in the $\mathrm{K}$ and $\mathrm{Fe}$ contents. There- fore, the source of Unit II is likely to be the nearby limestone strata (i.e., the Hengchun Limestone), and material fell into the riverbed and was then buried by terrestrial muddy sediments. Therefore, the bottom of the GC core is considered to represent the incipient stage of the deposition and burial of the early river valley, which began at approximately $16.5 \mathrm{ka}$. The location and height of these two units might be close to the original bedrock strath or near the slope.

Unit III is between -22.9 and $-11.9 \mathrm{~m}$ in the core, corresponding to -9.1 to $+1.9 \mathrm{~m}$ relative to the current sea level. This unit features gray-colored horizontal laminae, massive silt, and fine sand, with occasional interlayers of yellow mud and dark gray fine sand. It also contains massive mud and sand sublayers and features another four layers of sandstone, shale and limestone breccia that are less than $20 \mathrm{~cm}$ in thickness. Unit III contains high $\mathrm{K}$ and Fe values and low $\mathrm{S}$ and $\log (\mathrm{Ca} / \mathrm{Ti})$ values. From these features, this unit was likely formed as sediments deposited in various environments on a low-energy flood plain, such as abandoned river channels, oxbow lakes, ponds, swamps, etc. On the top section of this layer, approximately $1.3 \mathrm{~m}$ above sea level, wood was dated to 8585 - $8480 \mathrm{cal}$. BP. The buried tree trunks described in the GY area (Fig. 6b) roughly correspond to this section $(-1.5$ to $+1 \mathrm{~m}$ of sea level); therefore, this layer might be the fringe of the floodplain, and the trees were buried during the later aggradation stage.

Unit IV is at -11.9 to $-3.6 \mathrm{~m}$ in the core, corresponding to +1.9 to $+10.2 \mathrm{~m}$ above sea level. It is composed of greenish-gray-colored silt with horizontal and wavy laminae structures. The unit contains abundant organic matter, shell fragments, and pumice. This layer has significantly high $\mathrm{S}$ and $\log (\mathrm{Ca} / \mathrm{Ti})$ values and relatively low $\mathrm{K}$ and $\mathrm{Fe}$ values. The Gangkou River flows toward the Pacific Ocean, and the tidal magnitude at the river mouth is less than $2 \mathrm{~m}$, indicating a microtidal coastal environment. The sedimentary environment was likely a wave-dominated estuary with a low-energy water body, such as a lagoon (Dalrymple et al. 1992; Boggs 2006). We conclude that Unit IV was deposited in a lagoon-like environment. Wood recovered from +4.3 $\mathrm{m}$ a.s.l. was dated to $8380-8315 \mathrm{cal}$. $\mathrm{BP}$, wood from $+6.5 \mathrm{~m}$ a.s.l. was dated to $8000-7960 \mathrm{cal}$. BP, and wood from +9.6 m a.s.l. was 7590 - 7520 cal. BP. Furthermore, the pumice discovered at a depth of $-5.7 \mathrm{~m}$ may have been transported by the Kuroshio Current from the volcanic islands of the Luzon arc according to Song et al. (2004).

Unit $\mathrm{V}$ is at the top of the core and is between -3.6 and $0.0 \mathrm{~m}$ in the core, corresponding to +10.2 to +13.8 $\mathrm{m}$ above sea level. It is mainly composed of agricultureaffected brown-yellow soil with mottled structure. Unit V contains higher Fe values than the other units, but this could be from modern agricultural disturbance. In Unit IV, the $\mathrm{S}$ and $\log (\mathrm{Ca} / \mathrm{Ti})$ values decrease upward, and $\mathrm{K}$ increases upward, so Unit V likely was likely deposited on the flood plain during the large-scale aggradation period. 


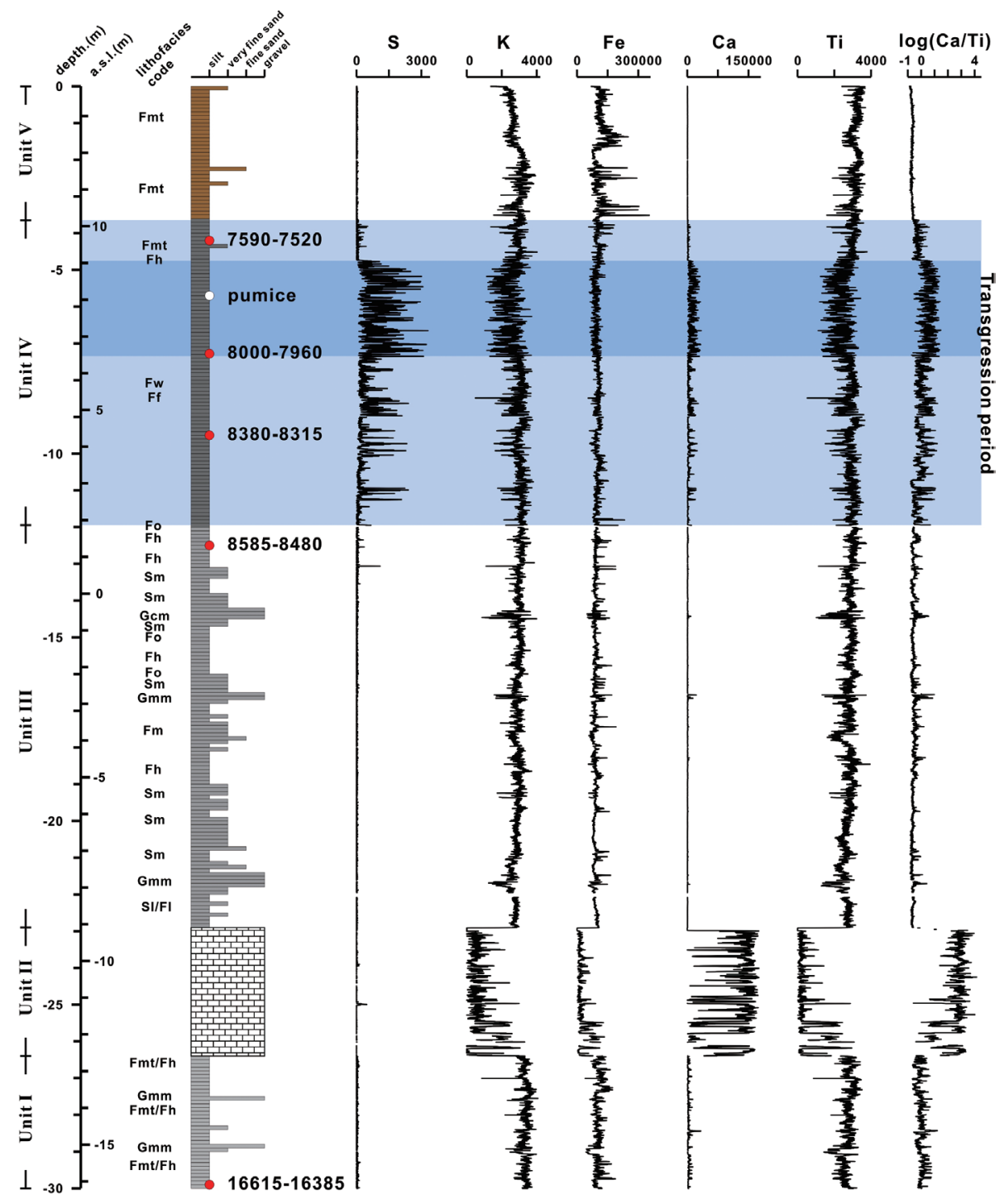

Fig. 8. The results of lithofacies analysis, XRF-CS analysis and radiocarbon dating of the GC core. The GC core was collected from the high terrace on the right bank approximately $0.9 \mathrm{~km}$ from the river mouth. Its coordinates are N21.9873, E120.8367, and its elevation is $13.8 \mathrm{~m}$ above sea level. The lithofacies features can be divided into five units. Unit IV at depths of -11.9 to $-3.6 \mathrm{~m}$ (1.9 to $10.2 \mathrm{~m}$ a.s.1.) can be considered a transgressive environment because of its lithofacies and remarkable marine signals. The other four layers belong to a continental depositional environment. 
Combining all the age data and elevations of the samples, we calculated the average deposition rate. From the bottom of the core to the top of Unit III, the deposition rate was approximately $2.2 \mathrm{~mm} \mathrm{yr}^{-1}$. From the top of Unit III to the top of Unit IV, the deposition rate was $8.5 \mathrm{~mm} \mathrm{yr}^{-1}$. The top of the core represented the end of deposition in this area, and since no suitable material was found for dating, we used the deposition rate immediately below the current layer, which was $8.5 \mathrm{~mm} \mathrm{yr}^{-1}$, to estimate the age of the top of the core, yielding an age of $7.1 \mathrm{ka}$.

\section{DISCUSSION}

\subsection{Timing and Reasons for Aggradation in the Gangkou River Valley}

Although the total thickness of the high terrace deposits was unknown even after exhaustive field work, the underlying bedrock straths only crop out in the MS area and are not visible in other areas (Fig. 3b). The present river valley in the MS area was formed from the meandering and lateral motion of the meander belt. These processes swept the entire river valley, eroded materials deposited before $11.2 \mathrm{ka}$ until $6.1 \mathrm{ka}$ and formed a new erosional surface. In the MS area, bedrock straths crop out in the high terraces, low terraces, and modern riverbed. This area is also the upper limit of the underfit stream landscape, which indicates that extensive lateral erosion and later aggradation reached only as far as this area and did not extend upstream from here. Farther upstream from the MS area (between Sianglin and Bayao, see Fig. 2), the river valley width is approximately equal to the width of the meanders. On the side of the river valley, many unpaired terraces formed by the migration and incision of the river. The features of the unpaired terraces are significantly different from those of the paired terraces downstream.

In contrast to the MS area, the bottom of the GC core in the lower reach of the river is older than $16.5 \mathrm{ka}$ and is presumably similar in age to the bedrock strath immediately before the beginning of valley aggradation. This indicated that the beginning of aggradation occurred earlier in the GC core area than in the MS area. Aggradation was significant in this lower reach area, resulting in thick deposits in the GC core during this period. Unit IV in the GC core shows marine signals and represents both the period of aggradation and the post-ice age rise in sea level (Fig. 8). The end of aggradation in the GC core area, which was calculated by dividing the thickness of the aggradation deposits by the average aggradation rate calculated in the previous section, was approximately $7.1 \mathrm{ka}$. Therefore, large-scale aggradation of the Gangkou River started in the late Pleistocene after the last glaciation when the sea level began rising rapidly. The sea level rise was faster than the tectonic uplift of the eastern HP, resulting in widespread aggradation in the Gangkou River that was synchronous with the rising sea level.

\subsection{Processes of River Valley Aggradation and Holocene Maximum Flooding Surface (HMFS) in the Gangkou River}

According to the sedimentary facies in the GC core, the distribution of elements from XRF-CS analyses (Fig. 8), and field investigations of the river terraces, large-scale aggradation of the Gangkou River valley began before $16.5 \mathrm{ka}$. Deposits during this period featured subaerial exposure and contained landslide materials from the strata in the nearby slopes. The river valley may have been relatively far from the coast, so terrestrial-origin material is common in sediments deposited during this period. From the hillslope process, the sediments were interlayered brownish-yellow to gray sand and mud or were massive mud, which implied possible flood plain or oxbow lake types of sedimentary environments, indicating the intermittent existence of a water body. The river valley widened during this period due to the burial of the incised valley.

Unit IV features high $\mathrm{S}$ and $\log (\mathrm{Ca} / \mathrm{Ti})$ values and greenish-gray mud deposits (Fig. 8). Because the Gangkou River flows to the Pacific Ocean, and the coast has a low tidal magnitude but high wave energy, the mud layers in Unit IV were likely deposited in a very low-energy brackish still water body behind a barrier at the river mouth, such as a lagoon or estuary (Dalrymple et al. 1992; Boggs 2006). The average deposition rate was calculated to be $8.5 \mathrm{~mm} \mathrm{yr}^{-1}$. Based on this rate, the beginning of the salt water signal in the GC core started at approximately $8.5 \mathrm{ka}$, and by $7.5 \mathrm{ka}$, the sea level again fell below where the core was located. The most prominent salt water signal was between 6.5 and $9.1 \mathrm{~m}$ a.s.l. in the GC core, corresponding to the time between 8.0 and $7.7 \mathrm{ka}$. This period therefore represents the timing of the Holocene maximum flooding surface (HMFS) in this area (Fig. 9). Previous studies have shown that in northern, northeastern, central, and even southern Taiwan, the HMFS formed between 8 and $9 \mathrm{ka}$ (Chen et al. 2009; Su 2011; Chen 2016; Su et al. 2018). The timing of the HMFS in the Gangkou River was significantly later and is closer to the timing of the highest sea level. If the calculated average deposition rate of $8.5 \mathrm{~mm} \mathrm{yr}^{-1}$ is used, the depositional period of the Gangkou River would have ended at approximately $7.1 \mathrm{ka}$ and would have coincided with the timing of the highest sea level (Chen et al. 2020).

The mud layers (1.9 - $3.3 \mathrm{~m}$ a.s.1.) exposed in the modern beach of the Gangkou River mouth were deposited at approximately $8 \mathrm{ka}$ (Fig. 6e) with unconformity separating the mud and the overlying beachrock, but the deposits of the same time were higher in elevation in the GC core. This indicates that the mud layers near the beach were eroded later, while the mud in the GC core was deposited more continuously. Our synthesis indicates that the mud layers discovered in the modern beach were deposited near the central basin of this paleoestuary/lagoon (Boggs 2006; Day 
et al. 2012); Lüthgens et al. (2018) also propose a similar explanation. Because of this, the paleo-Gangkou River mouth was likely located farther oceanward from where the mud layer crops out. Therefore, the oceanic influence on the paleo-Gangkou River mouth and the paleoshoreline began before $8.5 \mathrm{ka}$ and disappeared after $7.5 \mathrm{ka}$. Finally, the part of the GC core representing deposition during the HMFS is located at approximately $6.5-9.1 \mathrm{~m}$ a.s.1., while concurrent deposition in the high terrace of $\mathrm{HC}$ was much higher at elevations greater than $13 \mathrm{~m}$ a.s.l. (approximately $13.0-17.5 \mathrm{~m}$ if $15.1 \mathrm{~mm} \mathrm{yr}^{-1}$ is used for the calculation and $17.0-19.6 \mathrm{~m}$ if an average deposition rate of $8.4 \mathrm{~mm} \mathrm{yr}^{-1}$ is used). Therefore, during the maximum flooding period, the affected area of the brackish water should have been between the GC core and HC high terrace (Fig. 9); specifically, the inner edge (specifically, the bay-head delta) of this lagoon/estuary at the time would have been $4.1 \mathrm{~km}$ inland along the current riverbed from the modern river mouth of the Gangkou River.

\subsection{Tectonic Uplift and River Incision}

The local tectonic uplift rate can be calculated from landforms that represent the ancient sea level at particular times, and their modern elevations can be corrected with a known sea level curve (Chen et al. 2020) to obtain the real amount of uplift. By dividing the corrected uplift by the time they were at ancient sea level, we obtained the tectonic uplift rate. The representative landforms in this study were the HMFS in the GC core (Figs. 8 and 9), the erosional surface below the marine terrace and erosional surface above the remnant mud (with beachrock overlying the mud) in the GY area (Fig. 6e), and the modern and ancient gradient between the GC core and $\mathrm{HC}$ area (Fig. 10). The river incision rate can also be calculated from surfaces representative of the paleoriverbed and their ages. In this study, the top of the $\mathrm{GC}$ core, the end of deposition in the GC core, the coastal remnant mud surface and the formation time of this erosional surface can be used to calculate the incision rate.

We lay out the calculations below:

Marine terrace deposits near the river mouth of the Gangkou River were dated to 5020 - 4900 cal. BP (Figs. 6d and 7). The sea level at the time was approximately $1.1 \mathrm{~m}$ higher than the modern sea level, and the base of the marine terrace deposit was $7.6 \mathrm{~m}$ a.s. 1 . It should be considered that the shell sample was deposited in the gap of the coral reef, which indicates that the age of the shell should be later than that of the coral reef. However, we cannot determine the depositional depth of the shell, and we can estimate only the growth depth of the coral reef. Coral reefs usually grow at a depth of $1 \pm 0.5 \mathrm{~m}$ below sea level in southern Taiwan (Inoue et al. 2011). Therefore, the area experienced uplift of approximately $7-8 \mathrm{~m}$ during the past 5000 years, with an average uplift rate of approximately $1.5 \mathrm{~mm} \mathrm{yr}^{-1}(1.41$ - $\left.1.61 \mathrm{~mm} \mathrm{yr}^{-1}\right)$. The deposits formed during the maximum flooding were at 6.5 - $9.1 \mathrm{~m}$ a.s.1. (-7.3 to $-4.7 \mathrm{~m}$ in the core) and have ages of approximately $8.0-7.7 \mathrm{ka}$. The sea level at $8.0 \mathrm{ka}$ was $6.2 \mathrm{~m}$ below the modern sea level, and the sea level at $7.7 \mathrm{ka}$ was $3.2 \mathrm{~m}$ below the modern sea level. The depositional depth is also considered to have been approximately $0-2 \mathrm{~m}$ below sea level according to similar paleoenvironmental records from the marine terraces at Ningpu and Chingpu on the eastern coast of Taiwan (Hsieh and Liew 2010). Therefore, the average uplift rate near the GC core was approximately $1.7 \mathrm{~mm} \mathrm{yr}^{-1}\left(1.59-1.84 \mathrm{~mm} \mathrm{yr}^{-1}\right.$ at 8.0 $\mathrm{ka}$ and $1.60-1.86 \mathrm{~mm} \mathrm{yr}^{-1}$ at $7.7 \mathrm{ka}$ ).

The horizontal distance along the riverbed between the $\mathrm{HC}$ high terrace and GC core is $2.2 \mathrm{~km}$, and the average gradient of the modern river reach is approximately $0.43 \%$ (Fig. 10). The GC core had a boundary in the deposits corresponding to a clear change from ocean signals to terrestrial signals. This boundary formed at approximately $7.5 \mathrm{ka}$ and is at an elevation of approximately $10.2 \mathrm{~m}$ a.s.l. This boundary is equivalent to the upper boundary that has been affected by sea water, which may be assumed to be $0 \mathrm{~m}$ a.s.l. If an average depositional rate of $8.4 \mathrm{~mm} \mathrm{yr}^{-1}$ is used and the elevation of the $7.5 \mathrm{ka}$ deposit of the HC terrace was 21.2 $\mathrm{m}$ a.s.l., the average gradient between $\mathrm{GC}$ and $\mathrm{HC}$ at 7.5 ka would have been $0.51 \%$. Even if a depositional rate of $15.1 \mathrm{~mm} \mathrm{yr}^{-1}$ is used, the average gradient between $\mathrm{HC}$ and GC would have been $0.49 \%$. That is, the average slope between GC and HC remained roughly the same regardless of which depositional rate values are used in the calculation. This finding appears to indicate that GC and $\mathrm{HC}$ have had the same uplift rate of $1.7 \mathrm{~mm} \mathrm{yr}^{-1}$. However, please note that this inference is a rough estimate because it is impossible to know the flow path, length and type of river at $7.5 \mathrm{ka}$.

The top erosional surface of the $8.0 \mathrm{ka}$ mud layers discovered in the modern beach was approximately $3.3 \mathrm{~m}$ above current sea level, while the overlying beachrock has been dated to 4550 - $4445 \mathrm{cal}$. BP (radiocarbon dating) and $4.68 \mathrm{ka}$ (OSL dating) (Fig. 6e). The beachrock is the result of the alternating wet and dry conditions that are commonly found along microtidal coasts in tropical, subtropical and low-latitude regions. Therefore, the beachrock is inferred to have formed in the intertidal zone environment and was aligned roughly parallel to the ancient sea level according to Vousdoukas et al. (2007). The sea level during the formation of the beachrock was approximately $1 \mathrm{~m}$ higher than the current sea level, and it was assumed that the depositional depth was $0 \mathrm{~m}$ a.s.l. There was a net uplift of $2.3 \mathrm{~m}$, so the average uplift rate at this site was approximately $0.5 \mathrm{~mm} \mathrm{yr}^{-1}$ $\left(0.49-0.51 \mathrm{~mm} \mathrm{yr}^{-1}\right)$ based on a combination of the ages produced by the two dating methods. This uplift rate is significantly lower than the uplift rates observed in the GC and $\mathrm{HC}$ areas. Likewise, the uplift rate calculated from the nearby marine terrace is much higher than that at this site. One of the possible explanations for the discrepancy in the uplift 


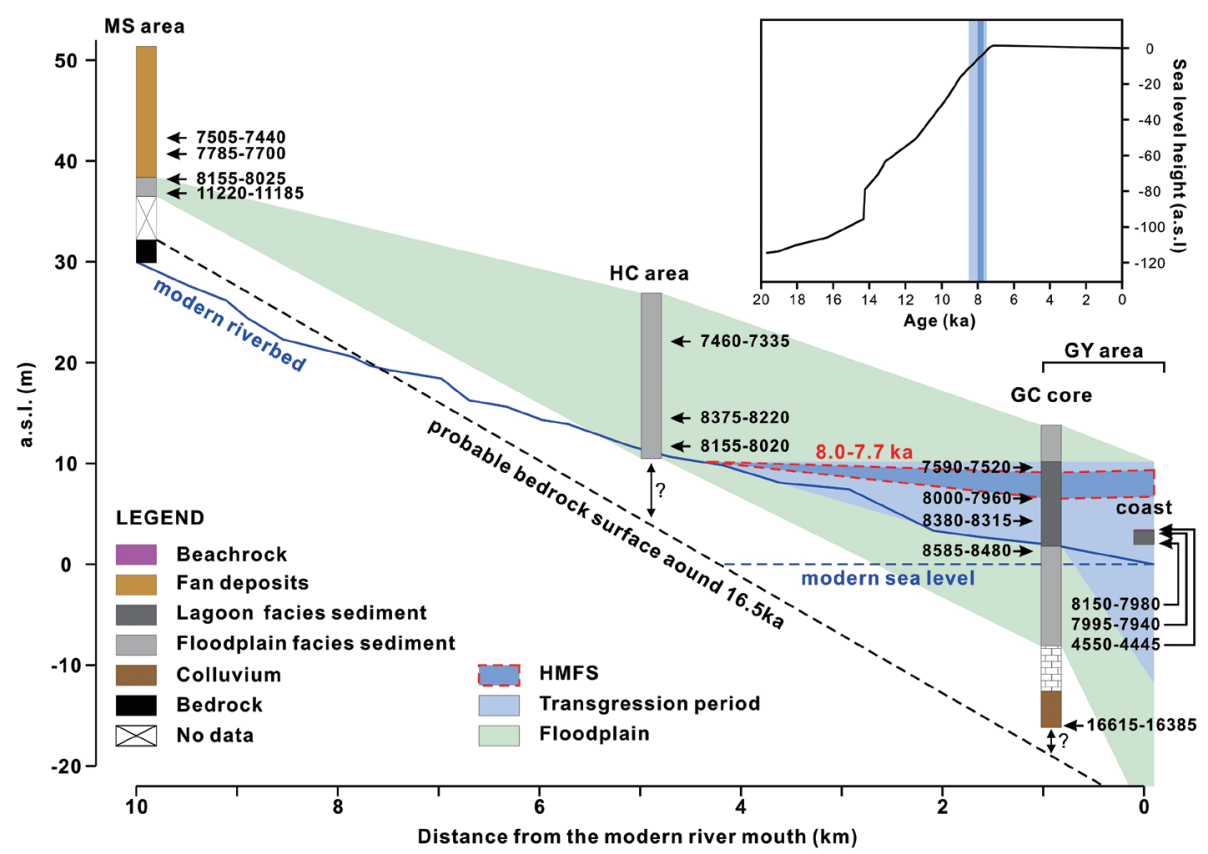

Fig. 9. Paleoenvironment contrast in the lower reach of the Gangkou trunk river. According to the above data, there are significant marine signals at elevations of 10.2 to $1.9 \mathrm{~m}$, indicating a transgressive environment. Among them, marine signals stood out at elevations of 6.5 to $9.1 \mathrm{~m}$. Obviously, the estimated age is approximately $8.0-7.7 \mathrm{ka}$, which could indicate the stage of the Holocene maximum flooding surface (HMFS). Furthermore, it could be estimated that the range of the transgression was approximately $4.1 \mathrm{~km}$ inland from the current river mouth to the upstream channel, which is near the confluence of the trunk stream and tributary Linlu River. The deposition rate of the remaining mud layer under the sand dune (Fig. 6e) was higher than that of other terraces, so we speculated that it may have been located close to the central basin of the lagoon.

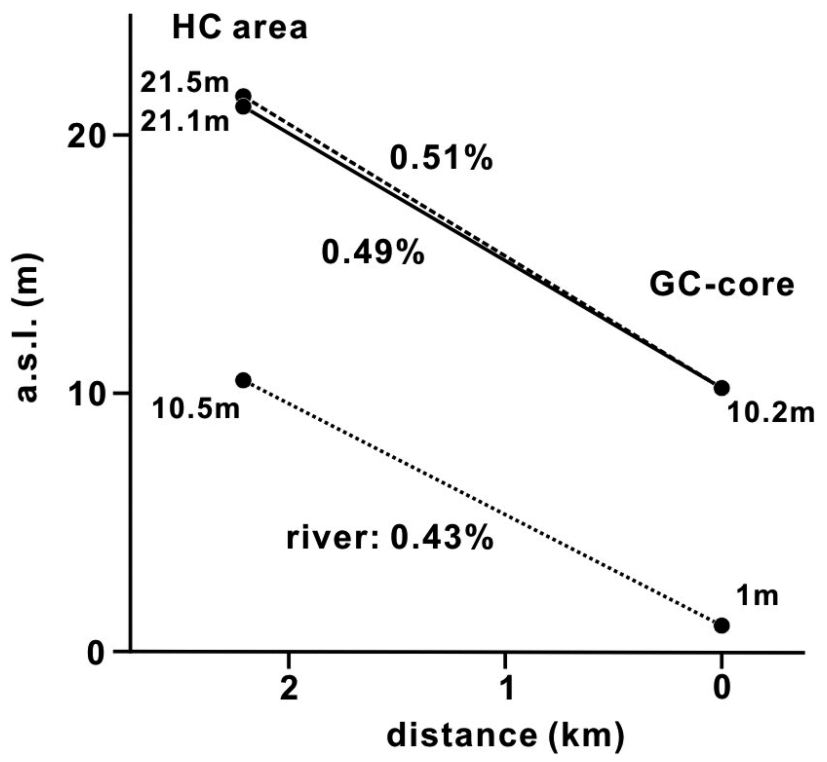

Fig. 10. Riverbed gradient comparison between the Huayuan-Ciaotou (HC) area and GC core. The calculation of the elevation of the riverbed in the $\mathrm{HC}$ area at $7.5 \mathrm{ka}$ is based on deposition rates of 8.3 and $15.9 \mathrm{~mm} \mathrm{yr}^{-1}$. See the text for a detailed discussion. 
rates in these locations could be the existence of an active fault. However, Lüthgens et al. (2018) proposed an alternative explanation and suggested that a north-dipping structure may have caused the uplift rate to decrease. At present, this study has no additional evidence to support these statements; therefore, this study does not discuss them furthers.

Regardless of the existence or activity of the fault or other geological structure, the various incision rates indicate that the river incision in the Gangkou River has not been steady over time. Aggradation ended at $7.1 \mathrm{ka}$ near the river mouth, and then the river started incising. The unconformity between the beachrock and the underlying mud layer on the coast (Figs. 6e and 7) indicates that the incision slowed at $4.5 \mathrm{ka}$. At this point, the river had achieved $70 \%$ of the total incision observed in this area, with an average incision rate of $4.0 \mathrm{~mm} \mathrm{yr}^{-1}$. The incision from $4.5 \mathrm{ka}$ to the present accounts for only $30 \%$ of the total incision in this area, with an average incision rate of approximately $0.7 \mathrm{~mm} \mathrm{yr}^{-1}$. This decrease in the incision rate seems to correspond to the time at which Lüthgens et al. (2018) proposed that the coastal area of the Gangkou River changed from uplift to subsidence. It may be possible to explain that when the sea level became more stable or close to the modern height, the incisional space was reduced, and aggregation increased. For landscape development between 7.1 and $4.5 \mathrm{ka}$, the Gangkou River was mostly in an incisional state. During this period, the paleocoastline and river mouth were retreating landward. From $4.5 \mathrm{ka}$ to the present, the river has been only slowly incising and has developed meanders and a wide river valley, which has helped form the high river terraces, wide river valley, and narrow riverbed. The coastline during this period remained mostly unchanged and was similar to the modern coastline.

\subsection{River Terraces, Thick Terrace Deposit Features and Landscape Evolution Process in the Gangkou Drainage Basin}

Following the previous results and discussions, we can conclude that there were five stages of landscape development in the lower drainage basin of the Gangkou River (Fig. 11).

(1) Stage 1: During the late glacial at approximately $16.5 \mathrm{ka}$. At this time, the paleo-Gangkou River featured an open $\mathrm{V}$-shaped valley, and the river mouth was very far oceanward and located approximately $100 \mathrm{~m}$ below the current sea level. The sea level increased quickly after the last glaciation from $14.3 \mathrm{ka}$ and reached its highest level at approximately $7.1 \mathrm{ka}$ (Chen et al. 2020). The average rising rate was $11.4 \mathrm{~mm} \mathrm{yr}^{-1}$, approximately $7-8$ times the land uplift rate. At the beginning of this stage, deposited sediments contained more colluvium from nearby areas or had substantial subaerial exposure time. As the aggradation of the river valley advanced and widened, the sediments deposited at this time on a low-energy flood plain were mostly brownish-yellow sand/mud.

(2) Stage 2: Between 8.5 and $7.5 \mathrm{ka}$, the sea level continued to rise, and the river mouth of the Gangkou River migrated inland. The coastline at the time remained outside the barrier of the current river mouth. Sea water flowed into the river mouth and affected the sediment compositions (observed in the GC core) and formed a low-energy, mostly still-water, lagoon-like environment. The HMFS occurred at approximately $8.0-7.7 \mathrm{ka}$ and affected an area $4.1 \mathrm{~km}$ inland from the modern coastline to between the GY area and the $\mathrm{HC}$ area, corresponding to heights of approximately $6.5-9.1 \mathrm{~m}$ above the current sea level. The edge of brackish water was between the GC core and HC area.

(3) Stage 3: Between 7.5 and $7.1 \mathrm{ka}$, the rising sea level reached its highest point, the lagoon environment was gradually filled with river sediments, the area of the lagoon was reduced, and aggradation in the modern river mouth occurred oceanward from the GY area, forming a wide river valley with a flood plain. The coastline migrated inland as the lagoon gradually shrank.

(4) Stage 4: Between 7.1 and $4.5 \mathrm{ka}$, sea level slowly fell (Chen et al. 2020). The land around this area was uplifted slowly, the coastline slowly moved landward, and the lagoon shrank, resulting in the retreat of the brackish water signal oceanward on the inland side. The Gangkou River started the fast incision stage during this period. The modern high terraces that are $10-20 \mathrm{~m}$ above the modern riverbed formed gradually during this stage. The average incision rate at the time was $4.0 \mathrm{~mm} \mathrm{yr}^{-1}$, while the uplift rate was between 1.5 and $1.7 \mathrm{~mm} \mathrm{yr}^{-1}$.

(5) Stage 5: From $4.5 \mathrm{ka}$ to the present, sea level was relatively stable, and the incision slowed. The average incision rate was $0.7 \mathrm{~mm} \mathrm{yr}^{-1}$, which was half the contemporary land uplift rate mentioned in the previous paragraph. The barrier at the river mouth stabilized. Compared to the upstream MS, HC, and YL areas, the Gangkou River in this area began to exhibit lateral migration in the meander zone. The sediments deposited prior to $7 \mathrm{ka}$ were eroded by this lateral migration of the river, forming the high terraces and a wide river valley. A small distance south of the barrier of the river mouth, sand dunes developed after 3 ka (Lüthgens et al. 2018). During the Little Ice Age, the Gangkou River repeated the processes of aggradation and small-scale incision and formed the low terraces in the HC, YL, and GY areas. In the MS area, the river incised down to bedrock, while near the river mouth, sand dunes again developed. The entire study area approached the current landscape.

\section{CONCLUSION}

This research studied the river terraces, marine terrace 


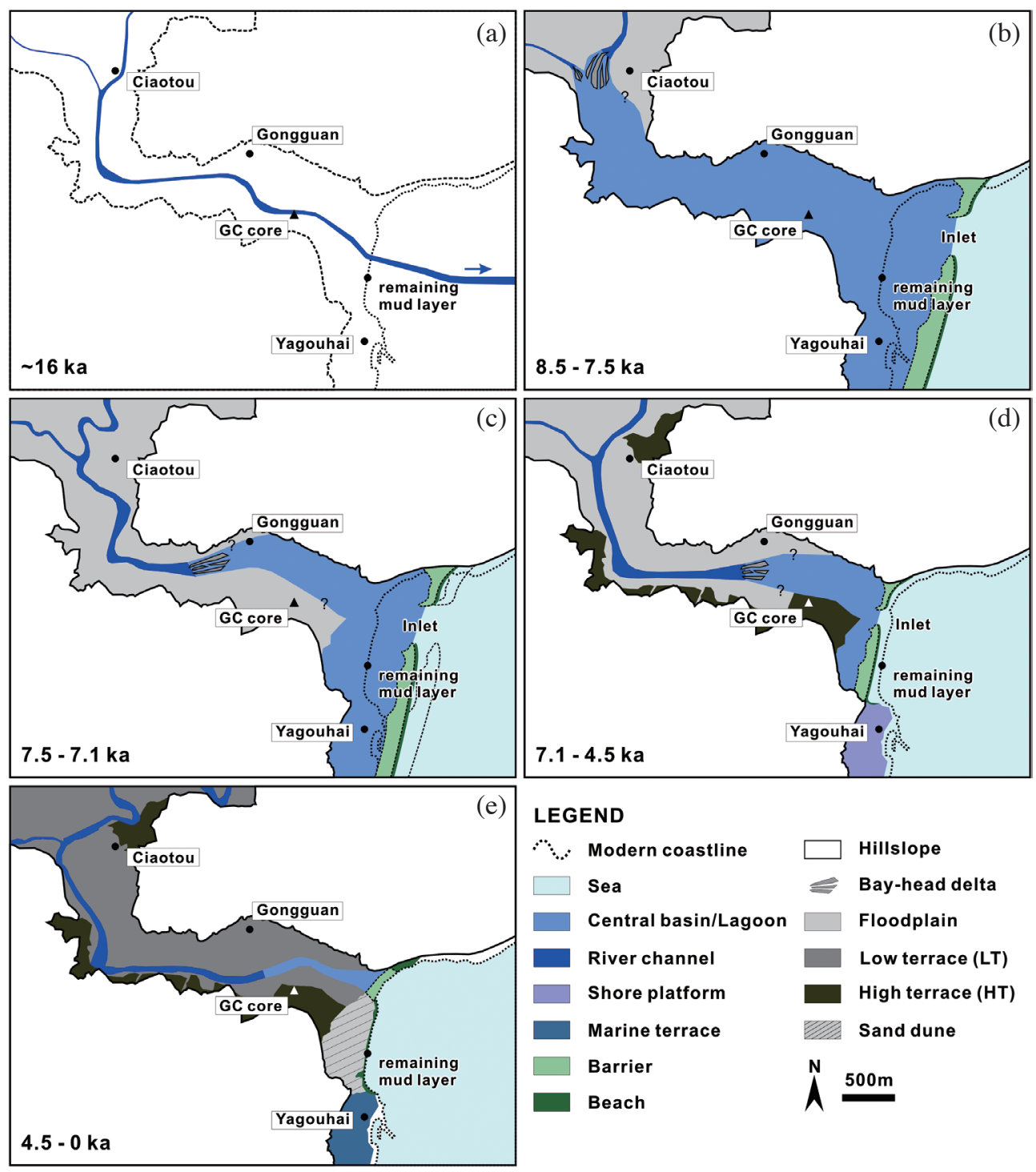

Fig. 11. Evolutionary models of the fluvial landscape in the lower reaches since the last glacial. (a) Between 16.5 and $8.5 \mathrm{ka}$, the sea level rose from approximately -106 to -11.2 m in eastern Taiwan. The Gangkou River likely resembled the V-shaped valley in the current upper reach and lacked a wide valley plain, and most of the deposits may have come from the surrounding slopes or adjacent areas. As the sea level rose, the area gradually transformed into meander and floodplain environments. (b) At 8.5 - $7.5 \mathrm{ka}$, because the rate of sea level rise was higher than the land uplift rate, the transgression reached the maximum range. The lagoon sediments deposited at this time indicated that barriers had developed outboard of the river mouth; otherwise, lagoon facies sediments could not have accumulated. (c) At 7.5 - 7.1 ka, the sea level reached its highest point. The land continued to uplift and supply terrigenous deposits, causing a regression. Wide floodplains developed, and the lagoon sediments were gradually covered by floodplain sediments. (d) At $7.1-4.5 \mathrm{ka}$, the sea level slowly fell. The fluvial process transitioned to incision and lateral erosion, forming the current high terraces. (e) From 4.5 ka to the present, fluvial erosion stabilized, and beachrock and sand dunes began to form. Repeated small-scale aggradation and incision are the reasons for the formation of the low terraces. 
and associated sediments along the Gangkou River to understand the influences of relative sea level changes and tectonic uplift on the downstream area of the Gangkou River, which features an underfit stream landscape. This research also clarified the tectonic motion over the last 10 thousand years in this area. We have reached following conclusions from this research.

(1) From the GC core, brackish water entered the downstream Gangkou River earlier than $8.5 \mathrm{ka}$ and left the Gangkou River later than $7.5 \mathrm{ka}$. The most prominent brackish water occurred at 8.0 - $7.7 \mathrm{ka}$, corresponding to the HMFS. Brackish water reached approximately $4.1 \mathrm{~km}$ inland from the modern coastline along the current riverbed. This is shown in the sediments of the core at an elevation of approximately $9.1-6.5 \mathrm{~m}$ a.s.1. in the downstream reach.

(2) Age dating of samples from the marine terrace, river terraces, and GC core showed that the average uplift rates were between 1.5 and $1.7 \mathrm{~mm} \mathrm{yr}^{-1}$. In the earlier stage between 14.3 and $7.1 \mathrm{ka}$, the sea level rose at a rate of $11.4 \mathrm{~mm} \mathrm{yr}^{-1}$, which was 7 to 8 times faster than the average uplift rate of the area. The relative difference in these rates over time was the main reason for the formation of the underfit stream landscape and the high and low terraces in this area.

(3) We identified five stages of landform development in the downstream section of the Gangkou River. Stage 1: From the late glacial period to $8.5 \mathrm{ka}$, the sea level rose, and the Gangkou River valley was filled by colluvium and floodplain deposits. Stage 2: Between 8.5 and 7.5 $\mathrm{ka}$, the sea level continued to rise and formed a lagoon environment near the river mouth in which brackish water sediments were deposited. From the sediment records, the HMFS occurred between 8.0 and $7.7 \mathrm{ka}$. Stage 3: Between 7.5 and $7.1 \mathrm{ka}$, the sea level reached its highest level, the area of the flood plain increased, and the lagoon moved outward, with the deposition of over $30 \mathrm{~m}$ of sediment in the downstream area. Stage 4: Between 7.1 and $4.5 \mathrm{ka}$, the slowly falling sea level and slowly uplifting land forced the seaward retreat of the coastline. This induced incision in the Gangkou River valley, forming high terraces with height differences of approximately $10-20 \mathrm{~m}$. Stage 5: Starting at $4.5 \mathrm{ka}$, prominent lateral migration and slow incision were the main processes in the region, forming a wide valley. Beginning 400 years ago in the Little Ice Age, repeated aggradation and incision processes formed low terraces with height differences between the terrace surface and modern riverbed of approximately $5 \mathrm{~m}$. These are the latest major geomorphic processes shaping the modern landscape of the Gangkou River.

Acknowledgements The authors thank Prof. N. T. Yu of National Tsing Hua University, Dr. C. Y. Lee of National
Taiwan University, and Prof. C. H. Lu of National Penghu University of Science for their valuable advice and discussion. We also acknowledge Prof. K. Y. Wei for help with the XRF-CS analysis and Prof. H. C. Li, Miss S. J. Kang, Miss C. Y. Chou, and Miss T. Y. Chang for performing the radiocarbon dating at the NTUAMS Lab of National Taiwan University. This study was financially supported by the Ministry of Science and Technology (MOST), Taiwan (grant numbers: 102-2119-M-259-001, 103-2119-M-259001, and 104-2119-M-259-004).

\section{REFERENCES}

Berryman, K. R., Y. Ota, and A. G. Hull, 1992: Holocene evolution of an estuary on a tectonically rising coast: The Pakarae River locality, eastern North Island, New Zealand. Sediment. Geol., 80, 151-165, doi: 10.1016/0037-0738(92)90038-S. [Link]

Boggs, S., 2006: Principles of Sedimentology and Stratigraphy (4th Edition), Pearson Prentice Hall, 662 pp.

Byrne, T. B. and C.-S. Liu, 2002: Preface: Introduction to the geology and geophysics of Taiwan. In: Byrne, T. B. and C.-S. Liu (Eds.), Geology and Geophysics of an Arc-continent Collision, Taiwan, Geological Society of America, Volume 358, Boulder.

Calvert, S. E. and T. F. Pedersen, 2007: Elemental proxies for palaeoclimatic and palaeoceanographic variability in marine sediments: Interpretation and application. In: Hillaire-Marcel, C. and A. De Vernal (Eds.), Developments in Marine Geology, Volume 1, Elsevier, UK, 567-644, doi: 10.1016/S1572-5480(07)01019-6. [Link]

Chang, C.-P., J.Angelier, T.-Q. Lee, and C.-Y.Huang, 2003: From continental margin extension to collision orogen: Structural development and tectonic rotation of the Hengchun peninsula, southern Taiwan. Tectonophysics, 361, 61-82, doi: 10.1016/S0040-1951(02)00561-9. [Link]

Chen, C.-L., C.-W. Lin, and W.-S. Chen, 2005a: A preliminary study on crustal deformation in Hengchun Peninsula, Southern Taiwan. Spec. Publ. Cent. Geol. Surv., 16, 55-73. (in Chinese with English abstract)

Chen, W.-S., 2016: Introduction to the geology of Taiwan. Geological Society of Taiwan, 204 pp. (in Chinese)

Chen, W.-S., W.-C. Lee, N.-W. Huang, I.-C. Yen, C.-C. Yang, H.-C. Yang, Y.-C. Chen, and S.-H. Sung, 2005b: Characteristics of Accretionary Prism of Hengchun Peninsula, Southern Taiwan: Holocene Activity of the Hengchun Fault. West. Pac. Earth Sci., 5, 129-154. (in Chinese with English abstract)

Chen, W.-S., C.-C. Yang, and H.-C. Yang, 2009: How to reconstruct the depositional framework of the late Quaternary subsurface sedimentary sequence in the Taiwan coastal plains? Spec. Publ. Cent. Geol. Surv., 
22, 101-114. (in Chinese with English abstract)

Chen, W.-S., N. Matsuta, Y.-K. Chu, N.-T. Yu, and H.-C. Yang, 2014: Holocene activity of the Hengchun fault in the southern Taiwan: Evidenced from the radiometric dating of uplifted coral reef terraces. Spec. Publ. Cent. Geol. Surv., 28, 1-18. (in Chinese with English abstract)

Chen, W.-S., C.-Y. Yang, S.-T. Chen, and Y.-C. Huang, 2020: New insights into Holocene marine terrace development caused by seismic and aseismic faulting in the Coastal Range, eastern Taiwan. Quat. Sci. Rev., 240, 106369, doi: 10.1016/j.quascirev.2020.106369. [Link]

Chen, Y.-G., 1993: Sea-level change and neotectonics in southern part of Taiwan region since late Pleistocene. Ph.D. Thesis, National Taiwan University, Taiwan, 158 pp. (in Chinese with English abstract)

Chen, Y.-G. and T.-K. Liu, 1993: Holocene radiocarbon dates in Hengchun Peninsula and their Neotectonic implications. J. Geol. Soc. China, 36, 457-479.

Clement, A. J. H., C. R. Sloss, and I. C. Fuller, 2010: Late Quaternary geomorphology of the Manawatu coastal plain, North Island, New Zealand. Quat. Int., 221, 3645, doi: 10.1016/j.quaint.2009.07.005. [Link]

Croudace, I. W., A. Rindby, and R. G. Rothwell, 2006: ITRAX: Description and evaluation of a new multifunction X-ray core scanner. In: Rothwell, R G. (Ed.), New Techniques in Sediment Core Analysis, Geological Society of London, London, 51-63, doi: 10.1144/ GSL.SP.2006.267.01.04. [Link]

Dalrymple, R. W., B. A. Zaitlin, and R. Boyd, 1992: Estuarine facies models; conceptual basis and stratigraphic implications. J. Sediment. Res., 62, 1130-1146, doi: 10.1306/d4267a69-2b26-11d7-8648000102c1865d. [Link]

Day, J. W., A. Yáñez-Arancibia, W. M. Kemp, and B. C. Crump, 2012: Introduction to estuarine Ecology. In: Day, J. W., B. C. Crump, W. M. Kemp, and A. YáñezArancibia (Eds.), Estuarine Ecology, Second Edition, Wiley-Blackwell, 1-18, doi: 10.1002/9781118412787. ch1. [Link]

Dury, G. H., 1964: Principles of underfit streams. Geological Survey Professional Paper 452-A, United States Government Printing Office, Washington.

Dury, G. H., 1965: Theoretical implications of underfit streams. Geological Survey Professional Paper 452-C, United States Government Printing Office, Washington, C1-C43, doi: 10.3133/pp452C. [Link]

Giletycz, S., N. Loget, C.-P. Chang, and F. Mouthereau, 2015: Transient fluvial landscape and preservation of low-relief terrains in an emerging orogen: Example from Hengchun Peninsula, Taiwan. Geomorphology, 231, 169-181, doi: 10.1016/j.geomorph.2014.11.026. [Link]
Hayes, M. O., 1975: Morphology of sand accumulation in estuaries: An introduction to the symposium. In: Cronin, L. E. (Ed.), Geology and Engineering, Estuarine Research Vol. 2, Academic Press, New York, 3-22, doi: 10.1016/B978-0-12-197502-9.50006-X. [Link]

Heap, A. D. and S. L. Nichol, 1997: The influence of limited accommodation space on the stratigraphy of an incised-valley succession: Weiti River estuary, New Zealand. Mar. Geol., 144, 229-252, doi: 10.1016/ S0025-3227(97)00107-2. [Link]

Hsieh, M.-L. and S.-J. Chyi, 2010: Late Quaternary masswasting records and formation of fan terraces in the Chen-yeo-lan and Lao-nung catchments, centralsouthern Taiwan. Quat. Sci. Rev., 29, 1399-1418, doi: 10.1016/j.quascirev.2009.10.002. [Link]

Hsieh, M.-L. and P.-M. Liew, 2010: A New Version of Holocene Tectonic Uplift Rates along the Hua-Tung Coast of Eastern Taiwan. Bulletin of the Central Geological Survey, 23, 165-200. (in Chinese with English abstract)

Hsieh, M.-L., K.-E. Ching, S.-J. Chyi, S.-C. Kang, and C.Y. Chou, 2014: Late Quaternary mass-wasting records in the actively uplifting Pa-Chang catchment, southwestern Taiwan. Geomorphology, 216, 125-140, doi: 10.1016/j.geomorph.2014.03.040. [Link]

Huang, C.-Y., W.-Y. Wu, C.-P. Chang, S. Tsao, P. B. Yuan, C.-W. Lin, and K.-Y. Xia, 1997: Tectonic evolution of accretionary prism in the arc-continent collision terrane of Taiwan. Tectonophysics, 281, 31-51, doi: 10.1016/S0040-1951(97)00157-1. [Link]

Inoue, S., H. Kayanne, N. Matta, W. S. Chen, and Y. Ikeda, 2011: Holocene uplifted coral reefs in Lanyu and Lutao Islands to the southeast of Taiwan. Coral Reefs, $\mathbf{3 0}$, 581-592, doi: 10.1007/s00338-011-0783-x. [Link]

Ishihara, T., T. Sugai, and S. Hachinohe, 2012: Fluvial response to sea-level changes since the latest Pleistocene in the near-coastal lowland, central Kanto Plain, Japan. Geomorphology, 147-148, 49-60, doi: 10.1016/j.geomorph.2011.08.022. [Link]

Keith, M. L. and R. T. Degen, 1959: Geochemical indicators of marine and fresh-water sediments. Abelson, P. H. (Ed.), Researches in Geochemistry, John Wiley and Sons, 38-61.

Kung,C.-L.and S.-J.Chyi,2012: The Study of River Terraces and the Neotectonic Implications of the Southern Huatung Longitudinal Valley. Environment and Worlds, 24-25, 93-114, doi: 10.6304/EAW.2012.24/25.4. (in Chinese with English abstract) [Link]

Lee, C. H., K.-E. Ching, C.-P. Chang, R.-J. Rau, and C.L. Chen, 2014: Movement of the active fault in the Hengchun Peninsula triggered by the 2006 Pingtung offshore earthquake based on the 2002-2013 geodetic data. Spec. Publ. Cent. Geol. Surv., 28, 207-230. (in Chinese with English abstract) 
Litchfield, N. J. and K. R. Berryman, 2005: Correlation of fluvial terraces within the Hikurangi Margin, New Zealand: Implications for climate and baselevel controls. Geomorphology, 68, 291-313, doi: 10.1016/j. geomorph.2004.12.001. [Link]

Litchfield, N. J. and K. J. Clark, 2015: Fluvial terrace formation in the lower Awhea and Pahaoa River valleys, New Zealand: Implications for tectonic and sealevel controls. Geomorphology, 231, 212-228, doi: 10.1016/j.geomorph.2014.12.009. [Link]

Litchfield, N. J., K. Wilson, K. Berryman, and L. Wallace, 2010: Coastal uplift mechanisms at Pakarae River mouth: Constraints from a combined Holocene fluvial and marine terrace dataset. Mar. Geol., 270, 72-83, doi: 10.1016/j.margeo.2009.10.003. [Link]

Lüthgens, C., L.-D. Ho, N. Clemenz, J.-H. Chen, C.-H. Jen, J.-Y. Yen, and S.-J. Chyi, 2018: The Holocene paleoenvironmental history of the Gangkou River estuary, Hengchun Peninsula, Taiwan. Terr. Atmos. Ocean. Sci., 29, 547-576, doi: 10.3319/TAO.2018.05.07.01. [Link]

Miall, A. D., 1978: Lithofacies types and vertical profile models in braided river deposits: A summary. In: Miall, A. D. (Ed.), Fluvial Sedimentology, Canadian Society of Petroleum Geologists, Calgary, Canada, 597-604.

Miall, A. D., 1996: The Geology of Fluvial Deposits: Sedimentary Facies, Basin Analysis, and Petroleum Geology, Springer-Verlag Berlin Heidelberg, 582 pp, doi: 10.1007/978-3-662-03237-4. [Link]

Ota, Y., K. R. Berryman, A. G. Hull, T. Miyauchi, and N. Iso, 1988: Age and height distribution of holocene transgressive deposits in eastern North Island, New Zealand. Palaeogeogr. Palaeoclimatol. Palaeoecol., 68, 135151, doi: 10.1016/0031-0182(88)90036-3. [Link]

Ota, Y., T. Miyauchi, and A. G. Hull, 1990: Holocene marine terraces at Aramoana and Pourerere, eastern North Island, New Zealand. New Zealand Journal of Geology and Geophysics, 33, 541-546, doi: 10.1080/00288306.1990.10421372. [Link]

Reimer, P. J., E. Bard, A. Bayliss, J. W. Beck, P. G. Blackwell, C. B. Ramsey, C. E. Buck, H. Cheng, R. L. Edwards, M. Friedrich, P. M. Grootes, T. P. Guilderson, H. Haflidason, I. Hajdas, C. Hatté, T. J. Heaton, D. L. Hoffmann, A. G. Hogg, K. A. Hughen, K. F. Kaiser, B. Kromer, S. W. Manning, M. Niu, R. W. Reimer, D. A. Richards, E. M. Scott, J. R. Southon, R. A. Staff, C. S. M. Turney, and J. van der Plicht, 2013: IntCal13 and Marine13 Radiocarbon Age Calibration Curves 0-50,000 Years cal BP. Radiocarbon, 55, 1869-1887, doi: 10.2458/azu_js_rc.55.16947. [Link]

Rothwell, R. G. and I. W. Croudace, 2015: Micro-XRF studies of sediment cores: A perspective on capability and application in the environmental sciences. In: Croudace, I. W. and R. G. Rothwell (Eds.), Micro-
XRF Studies of Sediment Cores, Developments in Paleoenvironmental Research, Vol. 17, Springer, Dordrecht, Netherlands, 1-21, doi: 10.1007/978-94-0179849-5_1. [Link]

Schumann, R. R., S. A. Minor, D. R. Muhs, and J. S. Pigati, 2014: Landscapes of Santa Rosa Island, Channel Islands National Park, California. Monographs of the Western North American Naturalist, 7, 48-67, doi: 10.3398/042.007.0108. [Link]

Schumann, R. R., J. S. Pigati, and J. P. McGeehin, 2016: Fluvial system response to late Pleistocene-Holocene sea-level change on Santa Rosa Island, Channel Islands National Park, California. Geomorphology, 268, 322340, doi: 10.1016/j.geomorph.2016.05.033. [Link]

Song, S.-R., C.-M. Liu, C.-H. Chen, and W. Lo, 2004: Pumice layers in marine terraces: Implications for tectonic uplift rates on the east and northeast coasts of Taiwan over the last hundreds of years. Quat. Int., 115-116, 83-92, doi: 10.1016/S1040-6182(03)00098-3. [Link]

Su, C.-C., 2011: The last interglacial depositional environment and tectonic characteristics of the Ilan Plain, northeastern Taiwan. Master Thesis, National Taiwan University, Taipei City, Taiwan, 129 pp. (in Chinese with English abstract) [Link]

Su, P.-J., T.-C. Chi, T.-W. Su, and L.-S. Teng, 2018: Facies Characteristics and Depositional History of the Sungshan Formation, Taipei Basin. West. Pac. Earth Sci., 15-18, 19-52. (in Chinese with English abstract)

Suppe, J., 1981: Mechanics of mountain-building and metamorphism in Taiwan. Mem.Geol.Soc.China, 4, 67-89.

Suppe, J., 1984: Kinematics of arc-continent collision, flipping of subduction, and back-arc spreading near Taiwan. Mem. Geol. Soc. China, 6, 21-33.

Van der Schriek, T., D. G. Passmore, J. Rolão, and A. C. Stevenson, 2007: Estuarine-fluvial floodplain formation in the Holocene Lower Tagus valley (Central Portugal) and implications for Quaternary fluvial system evolution. Quat. Sci. Rev., 26, 2937-2957, doi: 10.1016/j.quascirev.2007.07.020. [Link]

Vis, G.-J. and C. Kasse, 2009: Late Quaternary valleyfill succession of the Lower Tagus Valley, Portugal. Sediment. Geol., 221, 19-39, doi: 10.1016/j.sedgeo.2009.07.010. [Link]

Vis, G.-J., C. Kasse, and J. Vandenberghe, 2008: Late Pleistocene and Holocene palaeogeography of the Lower Tagus Valley (Portugal): Effects of relative sea level, valley morphology and sediment supply. Quat. Sci.Rev., 27, 1682-1709, doi: 10.1016/j.quascirev.2008.07.003. [Link]

Vis, G.-J., S. J. P. Bohncke, H. Schneider, C. Kasse, S. Coenraads-Nederveen, K. Zuurbier, and J. Rozema, 2010: Holocene flooding history of the Lower Tagus Valley (Portugal). J. Quat. Sci., 25, 1222-1238, doi: 10.1002/jqs.1401. [Link] 
Vousdoukas, M. I., A. F. Velegrakis, and T. A. Plomaritis, 2007: Beachrock occurrence, characteristics, formation mechanisms and impacts. Earth-Sci. Rev., 85, 2346, doi: 10.1016/j.earscirev .2007.07.002. [Link]

Wilson, K., K. Berryman, U. Cochran, and T. Little, 2007a: Early Holocene paleoseismic history at the Pakarae locality, eastern North Island, New Zealand, inferred from transgressive marine sequence architecture. Tectonics, 26, TC4013, doi: 10.1029/2006TC002021. [Link]

Wilson, K., K. Berryman, U. Cochran, and T. Little, 2007b: A Holocene incised valley infill sequence developed on a tectonically active coast: Pakarae River, New Zealand. Sediment. Geol., 197, 333-354, doi: 10.1016/j. sedgeo.2006.10.007. [Link]
Yang, R.-Y., Y.-C. Wu, and H.-H. Hwung, 2012: Beach Erosion Management with the Application of Soft Countermeasure in Taiwan. In: Curkovic, S. (Ed.), Sustainable Development - Authoritative and Leading Edge Content for Environmental Management, IntechOpen, 349-370, doi: 10.5772/45883. [Link]

Yu, H.-S. and J. C. Lu, 1995: Development of the shale diapir-controlled Fangliao Canyon on the continental slope off southwestern Taiwan. J. Southeast Asian Earth Sci., 11, 265-276, doi: 10.1016/07439547(95)00004-C. [Link]

Yu, S.-B., H.-Y. Chen, and L.-C. Kuo, 1997: Velocity field of GPS stations in the Taiwan area. Tectonophysics, 274, 41-59, doi: 10.1016/S0040-1951(96)00297-1. [Link] 